\title{
Responses of Private and Public Schools to Voucher Funding: The Czech and Hungarian Experience
}

\author{
By: Randall K. Filer and Daniel Münich
}

Working Paper Number 360

October 2000 


\title{
Responses of Private and Public Schools to Voucher Funding: The Czech and Hungarian Experience*
}

\author{
Randall K. File \\ Daniel Münich
}

October 2000

JEL Classification: I22, J24, H52

Keywords: Educational Finance, Government Expenditures and Education, Occupational Choice, Labor Productivity.

\footnotetext{
* This research was supported in part by grant \#98-1-152 from the Social Consequences of Economic Transformation in East Central Europe (SOCO) program of the Institut für die Wissenschaften vom Menschen, Vienna. The Retrospective data survey was supported by PHARE (CZ 9406 01-01-03) and the National Council for East European and Euroasian Studies (812-32). We would like to thank Miroslav Prochazka and Michaela Klenhova from the Institute for Information in Education for information and expert assistance. We also appreciate valuable comments by Andrew Austin and Stepan Jurajda, and comments from participants at CERGE-EI Seminar Series and Czech Economic Society seminar. Address correspondence to Randall K. Filer, Department of Economics, Hunter College, 695 Park Avenue, New York, NY 10021; e-mail rfiler@hunter.cuny.edu. Address correspondence to Daniel Munich, CERGE-EI, P.O.Box 882, Politickych veznu 7, 11121 Prague, Czech Republic; e-mail: munich@cesnet.cz.

${ }^{1}$ Randall K. Filer is Professor of Economics at Hunter College and the Graduate Center, CUNY and CERGE-EI, Prague, a joint workplace of Charles University and the Academy of Sciences of the Czech Republic.

${ }^{2}$ Daniel Munich is Assistant Professor of Economics at CERGE-EI. Both are Research Associates of the William Davidson Institute of the University of Michigan.
} 


\begin{abstract}
A state monopoly in schooling followed the collapse of communism in Central Europe. The centrally planned system was abandoned. Systems comparable with educational voucher scheme, also known as school choice system, were introduced in the Czech Republic and Hungary in the early 1990s. The newly established system of school financing allocates public funds according to the number of students enrolled in a school. Accredited non-state schools, private and religious, are also eligible for public subsidies. The scope and the form of these reforms represent a unique opportunity to test conflicting hypotheses of proponents and opponents of the voucher scheme.

In this empirical analysis, we test fundamental theoretical predictions of the voucher model. Specifically, we test: i) whether non-state schools are established at locations where the supply of educational opportunities provided by state schools is low or of low quality, ii) whether state and non-state schools in such a system respond to changes in demand for education, and iii) whether state schools respond to competition from non-state schools. We use detailed school level data on the whole population of schools and data on regional conditions. In our econometric model we estimate education value added, instead of relying on absolute quality of school graduates.

We find that non-state school emerge at locations with excess demand and lower quality state schools. We also find that greater competition from non-state schools creates incentives for state schools with the result that state schools slightly improve the quality of educational inputs used and significantly improve their output, quality of graduates. As concerns the technical schools, we find that non-state schools react to regional labor market conditions in terms of technical branch premium and unemployment rate. We do not find such reactions to market signals by state schools.

We introduce this analysis with a review of non-state schools' development in the Czech Republic and Hungary during the 1990s.
\end{abstract}




\section{Introduction}

Some of the most profound changes following the collapse of communism in Central and Eastern Europe occurred in educational systems. For generations schools had served not only as a means of training workers, but also as a vehicle of indoctrination designed to create a "new socialist man." Education was, by law, a state monopoly designed to respond to the dictates of the plan rather than the signals of the market. Very detailed curricula were prescribed by central authorities (Micklewright, 1999). Parental and student preferences played little, if any, role in determining how much or what type of training was provided. Entry into coveted disciplines, while certainly influenced by ability, was also heavily determined by political or other considerations. There are numerous examples of students with an interest in and aptitude for study in particular subjects being forced info entirely unrelated fields because they or their parents were considered politically unreliable. ${ }^{1}$

In such an environment it is not surprising that one of the first reforms of the transition process was to overhaul the educational system to provide greater flexibility and give far more substantial decision-making power to students and parents. One key reform involved allowing non-state ${ }^{2}$ schools to challenge the state education monopoly. Table 1 shows the extent of nonstate education in various Central European countries by the middle of the first decade after the collapse of communism. Several trends stand out. In most countries in the region, non-state education has achieved only limited market share. In the Czech Republic, Slovakia and Hungary, however, the share of students in pon-state schools approaches that in closely related EU countries such as Germany and Austria. ${ }^{3}$ It is not a coincidence that these three countries

\footnotetext{
${ }^{1}$ One common technique was to offer university admission to the children of those in disfavor, but only in highly technical fields unrelated to their background or interests. Thus, a student who desired to study literature might be offered admission only to the faculty of mathematics. When the student was unable to pass, the authorities could say with a straight face that the student had not been denied access to education because of political considerations, while ensuring that he did not receive the benefits education conferred.

${ }^{2} \mathrm{We}$ will use the term non-state to refer to all types of education that is administered by non-government entities such as churches, foundations, profit making corporations and individuals. Schools operated by these entities may or may not receive funding from the state according to local laws and policies.
}

${ }^{3}$ It lags considerably behind the EU average of almost $16 \%$. This average is heavily influenced by very high non- 
provide the most generous level of state funding for private and religious schools. In each, funding may be as much as $100 \%$ of that provided to government schools. Poland provides a subsidy to non-state schools of approximately $50 \%$ of the funding given to state schools, while in most of the other countries of the region there is little or no public support for non-state schools.

Since our task is to learn what we can about the impact of voucher-like schemes from the experience of Central Europe, we will limit the discussion below to those countries where there is extensive public support for non-state schools. In addition, to keep the analysis tractable, we will ignore Slovakia, which has a similar history to that of the Czech Republic, and focus almost exclusively on the Czech Republic and Hungary. This paper traces the development of non-state schools $^{4}$ as well as other education reforms in these two countries since 1989. It provides preliminary evidence regarding the role of such schools in expanding the range of opportunities for parents and students and in bringing pressure for reform to bear on the state school system.

\section{A. Initial Conditions}

The Czech Republic has a population of about 10.3 million people and an area of just over 30,000 squares miles. In area it is almost exactly the same size as South Carolina, while the population is close to that of Michigan. Overall, in terms of area, population, and density, one would do well to think of the Czech Republic as a close mirror of Ohio. Administratively, prior to 2000, government functions were divided between the national government and 77 district or local governments. ${ }^{5}$ (Recently regional governments have been introduced between the national

state enrollments in countries such as France, Belgium and the Netherlands where the tradition is for each of several antagonistic linguistic or religious groups to operate independent school systems with state funding. Lack of private response in Poland could be due to Catholic authorities already capturing the public system. Big minorities have demand for private education, not small minorities.

\footnotetext{
${ }^{4}$ Non-state schools in the Czech Republic can be divided into two types, private and church sponsored. Among academic high schools, about 20 percent of non-state schools are church related. The church-related share of other types of schools is much lower. In Hungary church-affiliated schools comprise two-thirds of non-state academic high schools but 7 percent of technical high schools and 15 percent of vocational (apprentice) schools.

${ }^{5}$ There are actually a larger number of districts but we combine educational data for all jurisdictions in Prague into a single metropolitan area. Thus, we have data for greater Prague plus 76 additional districts.
} 
and district government levels but these did not exist during the period under study here.) Czech districts should be thought of as analogous to US counties in area, population and responsibilities. Studies of labor markets have found that there is surprisingly little commuting for employment across district boundaries, especially given the relatively small size of districts and the large differences in job opportunities (Erbenová, 1997). Mobility for employment was low even during communism and has declined further since 1990 (Andrle, 1998). Whether this is due to intense localism or poor transportation infrastructure, it suggests that there is also likely to be little commuting to attend schools that are in some way more attractive than those found nearby.

Hungary has a population of about 10.2 million in an area of slightly less than 36,000 square miles. Administratively, the country is divided into 19 counties and 8 cities of county status including Budapest. These administrative areas are on average, therefore, about three times the size of those in the Czech Republic.

Both educational systems provide several paths that students can follow. In 1989 ten years of schooling was compulsory. Primary education in the Czech Republic lasted for either eight or nine years. Talented students were allowed to apply for secondary education after eight years of primary school while others, particularly those who did not obtain their desired placement, remained for a ninth year. Then, as now, students applied for various types of secondary school depending on their future career plans, with admission to over-subscribed programs rationed on the basis of exam performance and other considerations. In Hungary primary education ended after eight years.

The lowest level of additional education available involves two years of vocational training. ${ }^{6}$ High school education is divided into three types: vocational education leading to a certification exam, specialized secondary (technical) education in professional fields such as nursing and engineering, and general secondary education in academic high schools known as

\footnotetext{
${ }^{6}$ Except for Czech students who sometimes studied only for one more year if they remained in primary schools for the full nine years possible.
} 
gymnázia. Students from secondary education may continue on to university although it is rare for those from vocational school to do so and the majority of university students come from academic high schools. ${ }^{7}$ As elsewhere in the region, university education typically involves the study of a single field and lasts five years. ${ }^{8}$ Students desiring the most advanced degree typically continue for another three years of post-graduate study.

Although educational levels were on average relatively high, the structure of education was highly skewed towards vocational and away from general academic training. In 1989-90 less than one-quarter of secondary students were enrolled in an academic, as opposed to technical, program in both the Czech Republic and Hungary. This percentage contrasts with slightly under half of secondary-level students in general academic programs in the average OECD country. In fact, in 1995 the Czech Republic had the lowest proportion of secondaryschool students in general academic programs of any OECD country (OECD, 1997). Furthermore, the vocational education system is very specialized. There are over 300 separate "tracks" in the Czech Republic, compared with 16 in Germany, a nearby country with heavy emphasis on vocational training (Laporte and Schweitzer, 1994).

The legacy of the allocation system imposed by the planning authorities has resulted in substantial excess demand for various types of education (CEPR, 1998). In 1989 only 52 percent of those seeking university admission in the Czech Republic were offered at least one place. It is not possible to reconstruct from official data the success rate of students seeking admission to

\footnotetext{
${ }^{7}$ In order to enroll in university students must leave secondary school with an exam credential known as a maturita. Whether or not a student receives this credential, and can therefore continue on to university studies, depends on their program or course of study. In the Czech Republic, all gymnázia and 96 percent of technical school programs, but only 14 percent of vocational school programs, lead to a maturita and the possibility of university admission. In fact, many vocational schools are three years or less in length and cannot provide the maturita required for university admission. There has arisen a market niche for schools providing what is known as "addendum" programs to allow such students to qualify for university.

${ }^{8}$ In addition to university, there are so-called "higher professional schools" in some specialized fields that form an intermediate level of education between secondary and true tertiary education. These were legally established as secondary schools in the Czech Republic because the law on higher education did not allow for non-state tertiary institutions before 1998 .
} 
academic high schools. ${ }^{9}$ It is widely understood, however, that more students seek admission to these schools than there are places available. Similarly, places in popular fields in technical and vocational high schools, especially those required for the expanding service sector, are severely rationed. Thus, there should be market niches that could be filled by entrepreneurial educational providers.

In addition, school systems in the Czech Republic and Hungary, as elsewhere in the region, have substantial weaknesses that may encourage parents to seek alternatives to public schools. In particular, the public school systems are overly focused on memorization rather than creative thinking (Tomášek et. al., 1997). Finally, some parents regard public schools with distrust, given their role in indoctrination under communism, a situation paralleling the attitudes of groups such as fundamentalist Christians in the U.S.

Development of regional educational systems during the 1990 s was driven by demographic trends as well as educational reforms. Table 2 shows the population at various ages in 1991 and 1999. It is clear that in both the Czech Republic and Hungary there were massive declines in birth rates during the final years of communism. Thus, at the start of the transition educational planners could foresee that the number of students of both primary and secondary school age would fall considerably over the decade. The number of children of high school age (between 14 and 17) fell by gver 25 percent between 1991 and 1999 in the Czech Republic and over 30 percent in Hungary. ${ }^{10}$ This demographic trend should have resulted in increased access to education over the decade even if there were no increase in educational spending or no new schools entering the market.

\footnotetext{
${ }^{9}$ Data is reported on the number of applications and the number of acceptances but not on the number of applicants.

${ }^{10}$ Although beyond the scope of this paper, we also note in Table 2 that the decline in Poland did not occur until several years after that in the Czech Republic and Hungary. Given this greater potential demand and the country's strong Catholic tradition, it is interesting to speculate as to why non-state schools are less common in Poland than in nearby countries. One obvious answer involves the lower support provided to such schools in Poland, but this begs the question of why elected officials in Poland did not find it necessary to support non-state education as extensively as their neighbors.
} 


\section{B. Educational Reforms Since 1989}

Beyond the lifting of the ban on non-state schools, there have been several major education reforms in the Czech Republic and Hungary since the start of the transition that may have played a role in the rise of such schools.

In each country individual schools were given legal status and decision-making authority over enrollment and curricula. The setting of the number of students allowed to enter various disciplines by centralized State Planning Commissions was abolished. Schools and teachers were given substantially greater freedom to chose teaching methods and textbooks. Even though there are school leaving exams for most programs, the form and content of these exams was left to the discretion of individual schools. These reforms provided all schools, both state and nonstate, with substantially increased ability to compete for students.

Prior to approximately 1992, all academic high schools were four-year programs. With the freedom allowed after 1989, a number of gymnázia began admitting students after the fourth or fifth or sixth year of primary school and revised their program so that it lasted between six and eight years. By the 1997/98 school year, these "extended gymnázia" accounted for over 40 percent of gymnázia students in the secondary-school years in the Czech Republic and about half that fraction in Hungary. There has been considerable discussion about the impact of this reform on primary schools. It is generally assumed that the more talented and academically motivated students leave primary school for the extended gymnázia, resulting in less classroom stimulation and lower probability of academic success for those left behind. If this is true, then the trend will be self-reinforcing and the share of extended gymnázia should continue to grow over time. It should be noted, however, that this reform developed independently of the rise of non-state schools. Indeed, the division between extended and conventional gymnázia is approximately the same in the state and non-state sectors in the Czech Republic, although in Hungary extended academic high schools form a greater fraction of non-state than state schools.

In addition to these common reforms, there have been major educational reforms that were specific to the Czech Republic since 1989 and need to be taken into account when studying 
the development of the educational sector since the transition. In particular, one reform adopted in 1995 to take effect in the 1996/97 school year profoundly affected enrollment trends in various types of schools. As discussed above, prior to this time the ninth year of primary school was optional, with most students opting to enter secondary school after the eighth grade. The main purpose of the ninth grade in primary school was to give students a chance to delay decisions about their educational future (especially if they wished to reapply to secondary schools to which they had been denied admission after the eighth grade) or to provide a stop-gap for students who did not wish to continue their education but completed the eighth grade below the statutory minimum age for employment. By the 1995/96 school year less than 5 percent of students completing the eighth grade continued on to a ninth grade in primary school, down from a high of almost 20 percent a few years earlier. This decline was due in part to shrinking overall numbers of students resulting from the demographic trends seen in Table 2, combined with increased opportunities provided by the rise of non-state secondary schools hiring reduced fraction of eighth grade students who were not able to secure admission to their desired type of secondary school. Education law amendments in 1995 rationalized the system by lowering the required years of schooling from ten to nine while making the ninth year of primary school mandatory for all students, increasing the normal age of admission to secondary school by one year.

Because of this change in the length of primary school, the number of students entering secondary school during the 1996/97 school year dropped drastically. Admissions to the high school grades in gymnázia fell from 26,800 in $1995 / 96$ to 15,700 in $1996 / 97$, before rising again to 26,700 in $1997 / 98$. The decline for other types of schools was even greater. Admissions to technical schools fell from 56,400 in $1995 / 96$ to 6,700 in $1996 / 97$, rising back to 56,400 in 1997/98. For vocational schools, the figures were 67,900 in $1995 / 96,8,100$ in $1996 / 97$ and 53,800 in 1997/98. Gymnázia were able to more successfully maintain enrollment due to the back-log of unsuccessful applicants from previous years, although there has been no investigation of the long-term prospects of this single class of presumably lower than average 
quality. Given that secondary school is typically a four-year program, this reduced cohort will be seeking university admission in the fall of 2000, presumably with the same impact on enrollments although, here again, the small cohort will represent an opportunity to reduce the back-log of excess demand created by slot-rationing in previous years. ${ }^{11}$

Finally, in the Czech Republic, there were traditionally a limited number of post-maturita secondary technical schools that typically provided job-specific training to students such as gymnázia graduates who did not seek university entrance but, instead, desired to be prepared for the labor force. Such schools enrolled only about 2,000 new students per year at the start of the 1990s, but had increased enrollment to around 10,000 new entrants per year by the middle of the decade. These programs (typically associated with existing secondary technical schools) were eliminated in the educational reforms of 1995 and replaced by a new type of institution known as a "higher professional school" as well as by a provision allowing students previously served by such post-maturita programs to simply join the third and fourth years of the conventional technical secondary school curricula. ${ }^{12}$ Higher professional schools also offered a technical way around the Czech ban on private universities by offering tertiary education under a different name.

The key reform of interest to us remains the rise of private and church schools. Such schools were first legalized in the Czech Republic in 1990. At first they were funded at a level equal to that provided state schools of the same type in the same area. Under pressure from education authorities, the principle of "equal treatment" for non-state schools was abandoned in

\footnotetext{
${ }^{11}$ Indeed, preliminary press reports indicate that applications for university enrollment for fall of 2000 are not substantially fewer than in normal years. Although it might have been expected that the number of applicants to university in 2000 would fall, in fact the number of applicants increased when compared to the previous year. Given that the number of secondary school graduates in June of 2000 was significantly reduced, this suggests that many applicants denied admission in previous years are taking advantage of the one-time opportunity to seek entry into highly demanded (and usually over-subscribed) programs. Impacts on the average quality of this cohort of "rejects" remain to be seen.

${ }^{12}$ By 1996 there were 165 of the newly formed higher professional schools enrolling between six and eight thousand new students per year. These schools represent a move towards what in other European countries is known as "nonuniversity higher education." Since these schools are still marginal and serve a different role from the core types of secondary schools we ignore them in the discussion below.
} 
1995, and the level of support for non-state schools was set equal to 60 to 90 percent of the subsidy provided to state schools, with the exact amount being set by the Ministry of Education and regional school authorities on the basis of unspecified performance criteria. Dissatisfaction with the arbitrariness of decisions regarding funding levels to non-state schools resulted in the law being amended again in 1999. Currently, public support for private schools is based on a two-part formula. Base support at the level of 50 percent of total support for state schools is given according to the type of school and is independent of quality or ownership. There is then a supplement that varies according to quality as evaluated by local schools offices (with final determination approved by a board at the Ministry of Education). Non-state schools can obtain maximum supplements equal to 90 percent of those available to state schools. In addition, the law now limits the discretion of the ministry and schools offices when evaluating quality to an explicit set of criteria. This policy was aqopted in order to protect non-state schools from arbitrary denial of funds by public officials. ${ }^{13}$

In Hungary, reflecting the looser form of communism that prevailed there during the 1980s, there were actually a limited number of religious academic high schools by 1989 . In particular, eight Catholic, one Protestant and one Jewish school enrolled over 3,600 students (about 3 percent of those in academic high schools at the time) with full funding from the state. In general these schools served young men who had expressed interest in religious vocations. After the start of the transition, the scope of activity of non-state schools was expanded and codified. Amendments in 1990 to the education law provided for "kindergartens, primary and secondary schools." The 1990 Act on Freedom of Conscience and Religion (Chapter 1, section 5) stated that "a religious legal entity can provide for any educational activity which is not exclusively reserved for the state." Finally, the 1994 Primary Education law and later rulings by the Constitutional Court established that the basic per student grant (the so-called "normative

\footnotetext{
${ }^{13}$ The difference in support is somewhat larger than these formulae would suggest since public schools are also eligible for capital funds for construction and maintenance from state sources. During the past decade such investment funds added about 10 percent to the level of support for state schools that was not available to non-state institutions.
} 
grant") plus other subsidies for "public duties" fulfilled by non-state schools must be provided on the same basis as state schools are supported.

Currently, therefore, educational spending in both countries is a function both of the formulae adopted for aid to schools and the total number of students enrolled. The authorities presumably could respond to changes in demand by changing the funding formula in order to keep total spending constant. Table 3 shows the development of public spending over the decade. During the 1990s there were significant variations in public spending on education both in amount per student and in share of the GDP in both the Czech Republic and Hungary. In the Czech Republic spending rose both in constant dollars and as a share of Gross Domestic Product (GDP) until the last years of the decade when it fell somewhat due to reduced cohort sizes and pressure on the state budget when economic growth slowed after 1997. Between 1991 and its peak in 1996, real spending per student increased by at least 37 percent. At the end of the decade it remained 16 percent higher than at the start of transition. Analysis in Hungary is complicated by its significantly greater rate of inflation (635\% between 1990 and 1999 as opposed to $290 \%$ in the Czech Republic). Filer and Hanousek (2000) have argued that inflation measures in transition economies contain substantial upward biases. If this is true, then real expenditures were substantially greater at the end of the decade than indicated in Table 3 and increased on a per student basis in both countries.

In addition to public spending, those running schools may be able to top up resources from their own funds. In Hungarian and Czech church-run schools such fees can be used only for value added services and tuition for fundamental education services is not allowed although "schools always find a legal way to collect money from parents (Aradi, Halász and Nagy, 1998)." Czech private schools generally do charge tuition fees, ${ }^{14}$ while church-sponsored schools are provided additional funds from congregational or diocesan resources for capital expenditures.

\footnotetext{
${ }^{14}$ In 1998 the mean annual tuition charged by non-state gymnázia was approximately 15,000 Czech crowns (\$450) with a range of from 1,500 crowns to 29,000 crowns. By way of reference, the mean annual wage during this year was approximately 150,000 crowns per worker while most households had at least two workers.
} 


\section{Changing Market Incentives}

One of the most profound changes during the transition from communism has been a rapid and sustained increase in the value of education. Filer, Jurajda and Plánovský $(1999,1998)$ and Munich, Svejnar and Terrell (1999) provide discussions of trends in returns to education in the Czech Republic while Svejnar (1999) summarizes research in other countries. Table 4 shows how much more workers who hold various diplomas or degrees earn than primary school graduates for the entire Czech workforce for selected years between 1984 and $1997 .{ }^{15}$ Clearly the value of all types of education has been increasing, with the greatest increase occurring for workers with general academic or specialized technical education. The figures in Table 4 are for workers of all ages combined. Results presented in Filer, Jurajda and Plánovský (1998) show that both levels of additional earnings and the increase in these levels associated with various degrees are greater for younger workers, even though many of them were trained under the communist regime. Presumably, the value of education provided after 1989, when curricula were free to adjust to the requirements of the market economy, would be even greater. There is not such exhaustive work on the pattern of wages in Hungary, but findings of existing studies are consistent with the Czech pattern shown in Table 4 (see Paihle, 1998 and Varge, 1995).

There is one area where economic conditions differed between the Czech Republic and Hungary during the 1990s that may have played a role in the development of the educational system. For most of the decade, unemployment in the Czech Republic was less than 4 percent, rising to a high of between 8 and 9 percent only in 1998 and 1999. In Hungary, by way of contrast, unemployment quickly shot up to almost 14 percent, and fell to around 9 percent only at the end of the decade. Since in both countries unemployment was greater among the less educated and the young, ${ }^{16}$ there should have been a second strong economic incentive to remain

\footnotetext{
${ }^{15}$ Although often called such in the literature, the results presented are not technically "returns to education" since they show only the private benefit of a given degree and ignore both social returns and the costs associated with that degree. Munich et al. (1999) show that these adjustments do not have a substantial impact in the Czech Republic.

${ }^{16}$ By way of illustration, in 1996, when the overall unemployment rate in Hungary was about 10 percent, the rate for
} 
in school during the decade. Based on the lack of employment opportunities, we might expect that the push to remain in school would have been greater in Hungary than in the Czech Republic, at least during the first years of the transition.

It would be surprising if individuals did not respond to such massive changes in private pecuniary returns. Indeed, Figure 1 shows that enrollment in secondary school as a fraction of the appropriate age cohort increased throughout the decade in both countries such that by 1998 enrollment was close to 100 percent among 14 to 17 year-old young men and women. ${ }^{17}$ In addition, as can be seen in Figure 1, the increase in enrollments was greater in those types of schools where the increase in returns was greatest (see Table 4).

A similar pattern can be seen in the demand for university education. Figure 2 shows the fraction of each cohort applying to and enrolling in university, where the "cohort" is defined as those who turn 18 in a given year. Given the high rejection rate among applicants, ${ }^{18}$ and the tendency for rejected applicants to reapply for several years, it is not appropriate, however, to infer that between 60 and 75 percent of eighteen-year-olds actually sought to go to university. It is also the case that the mean number of applications per applicant has been rising over time. In the Czech Republic the average number of applications per applicant increased from 1 (the limit allowed by the communists) in 1989 to 2.2 in 1992, after which it remained roughly constant at

youth 19 or younger was over 25 percent. Those with only primary education had a rate of about 15 percent while the rate for secondary school graduates was about half as large (Keune, 1998). Czech unemployment did not increase substantially until the end of the 1990s. In 1999 approximately 8 percent of university graduates were unemployed directly after leaving school, compared with around 13 percent of academic high school graduates, 15 percent of technical school graduates and 20 percent of vocational school graduates (UIV, 2000).

${ }^{17}$ Determination of the enrollment rates for the Czech Republic is complicated by the extension of primary school that occurred in 1996. We have omitted 14 year-olds from the relevant population in 1996 and later. The fact that there is no discontinuity in the trend line in Figure 1 (or any of the later figures) at this point suggests that this is approximately the correct adjustment. This may account for the apparent abnormality of enrollment rates reaching over 100 percent in 1996 and 1997, although, as discussed above, there may also have been some students who remained in secondary school beyond normal ages to acquire additional vocational training.

${ }^{18}$ In the mid-1990s roughly 80 percent of Czech gymnázium graduates, 37 percent of technical secondary school graduates and 22 percent of eligible vocational school graduates (i.e., the 8 to 10 percent of vocational school graduates who were enrolled in courses leading to the maturita) were successful in enrolling in university within two years of their graduation from secondary school. Obviously some graduates elect not to apply to university but overall places are still severely rationed. 
2.45 or less for the remainder of the decade.

\section{Growth of Non-state Schools}

Immediately after the collapse of communism, non-state schools became legal at the primary and secondary level. (Private universities, although allowed from the beginning of the transition in Hungary, were only allowed in the Czech Republic following amendments to the university education law in 1998.) Hungary and the Czech Republic differed in where non-state school arose. Despite their legality, there has been very little growth of non-state primary schools in the Czech Republic. By the 1998/99 school year there were only 33 private and 20 church related primary schools (1.3 percent of the total of 4,093 primary schools in the country), enrolling approximately 0.6 percent of all primary school pupils. Their role has been limited, frequently specializing in marginal students such as those needing special education or not able to adapt to normal school conditions. In Hungary, by way of contrast, in 1999177 churchaffiliated and 87 other primary schools (7.1 percent of the 3,696 primary schools in the country) enrolled 5.3 percent of primary school pupils.

At the secondary-school level the story is very different, with non-state education playing a more important role in the Czech Republic. From a base of zero in 1990, non-state secondary schools grew to approximately 25 percent of Czech institutions by the middle of the 1990s. Since the average private or church-related school was significantly smaller than the average public school, however, around 13 percent of students were enrolled in non-state secondary schools by the middle of the decade. Both the number of schools and the share of students enrolled in them appear to have leveled off by about the 1995/96 academic year and there has been little change since then. In Hungary, the share of non-state schools and enrollment rose

throughout the decade but by its end had reached only 15 percent of institutions enrolling 8 percent of students.

Table 5 ( $a$ and $b$ ) shows the number of state and non-state secondary schools of various types between 1989/90 and 1998/99. It is clear that, despite declines in the number of students in 
the relevant age range, there has not been a commensurate decrease in the number of secondary schools since educational reform began in 1990. Indeed, in the Czech Republic the total number of secondary schools increased by 49 percent from 1246 to 1859, down from a peak of 2116 in the 1995/96 school year. ${ }^{19}$ Two-thirds of this increase was accounted for by non-state schools, which grew from none to 448 institutions by the end of the decade (again down from a peak of 544 institutions two years earlier). Similarly, in Hungary, the total number of institutions increased from 1066 in 1989/90 to 1545 in 1998/99, with non-state secondary schools increasing from 10 to 238 during the decade. One implication of this increase, combined with the decline in the number of students in the relevant age range seen in Table 2, is that the average school size fell precipitously over the decade. Even allowing for the fact that a greater share of secondary students have enrolled in academic high schools than in the past, the average state academic high school in the Czech Republic in 1999 was 12 percent smaller than a decade ago, while enrollment in the average technical or vocational school shrank by over 40 percent. ${ }^{20}$ Because institutions tended to retain staff, the falling school size has meant that class sizes have also decreased steadily.

Table 6 ( $a$ and $b$ ) shows the total number of students in various types of schools over the decade while Figure 3 shows the share of the secondary-school aged cohort in state and non-state schools. It is clear that both the fraction of teen-agers enrolled in school and the share of secondary school students in non-state schools increased dramatically over the decade. From Figure 3 it is obvious that in the Czech Republic the share of the cohort in state schools was approximately the same at the end of the decade as at its start. Thus, the increase in overall enrollment over the decade was almost entirely due to the rise of non-state schools. In Hungary, by way of contrast, enrollment in state schools increased throughout the decade while non-state

\footnotetext{
${ }^{19}$ These figures exclude a small number of highly specialized schools such as dance and music academies.

${ }^{20}$ This obviously raises questions of over-capacity and excess spending on fixed plant. Although there have been attempts to close unneeded public schools, given entrenched bureaucracies and reluctance to commute long distances these attempts have met with only limited success.
} 
schools played a relatively smaller role in enhancing educational opportunities.

Figures 4 through 6 show visually the increase in the share of students in non-state secondary schools by type of school. There have been similar shifts across the districts away

from vocation towards technical and academic high schools. Again, this is in line with the shifting relative wages and unemployment probabilities discussed earlier. What does differ between the Czech Republic and Hungary is the relative importance of non-state schools of various types. In the Czech Republic non-state schools have attracted a smaller share of students in academic high schools (9.8 percent) than among technical schools (14.5 percent) or vocational schools (11.9 percent). In Hungary this pattern is reversed, with non-state schools having the largest share in academic high schools (14.5 percent) followed by technical high schools (7.3 percent) and vocational schools (5.2 percent).

\section{E. Perception of non-state schooling and parental school choice}

Introduction of a large-scale voucher-like school funding system requires sufficient public and political support. The opinions of the electorate, incumbent interest groups of teachers and school management, and parents of school-age children are therefore important. The actual behavior of parents considering placement of their children into a non-state school is, of course, a critical determinant of the success of the newly established non-state schools and their ability to elicit changes in the existing public schools. There is no conventional wisdom about these issues yet. Public debates are mainly driven by conflicting opinions based on limited personal experience, self-interest, or abstract theory.

To gain a better understanding of public perceptions regarding the issues of non-state school entry and competition effects that we investigated statistically we have also examined a 
representative sample of 1411 individuals surveyed in 199621. The survey asked individuals about their background and family status, children, and schooling related opinions and preferences. Using these data we look at the two major issues of interest. First, we identify the determinants of the perception of non-state schools among the adult population. Secondly, we identify factors influencing parents' actual school-choice.

\section{Perception of non-state schooling}

People responded to several statements about non-state schools using a 4-point rating scale ranging from strong agreement to strong disagreement. The frequency of answers to individual statements is reported in Table A2. Although answers are categorical, they are ordered. We employ a standard ordered logistic model to identify key determinants of individuals' opinions. Possible determinants of these opinions include: (1) employment as a

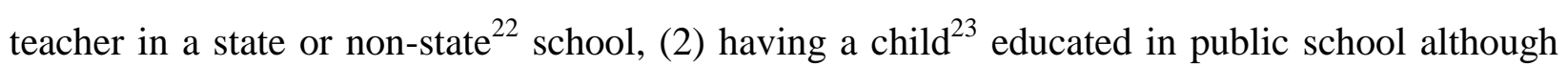
considering the choice of local schools limited or very limited, (3) having a child in private school while considering the choice of local schools as good or very good, (4) being well informed $^{25}$ about the state of the art in schooling, (5) years of education, (6) a quadratic in age, (7) earnings, (8) gender, (9) municipality size, and (10) marital status. In further description we

${ }^{21}$ The survey was conducted by Analysis Marketing Data (AMD) company and kindly provided for analytical purposes by the Institute for Information in Education (UIV).

${ }^{22}$ Private and church.

${ }^{23}$ The survey does not provide detailed information on each child if there is more than one in a family. There is no problem if a parent has only one child. If there are two or more children, the question "Are any of your children in a private school" does not provide comprehensive information.

${ }^{24}$ The survey asked two separate questions: one on own school choice and one on his or her opinion about existing choice among local schools. The survey did not ask for the specific reason for a specific school choice. By adding this variable we try to capture the impact of non-state school existence on availability of schooling opportunities.

${ }^{25}$ We consider individuals who have child(ren) in grammar, secondary school or university as more informed than the rest of the population, assuming that they had more opportunities and incentives to collect 
omit the last two variables because they did not appear to be significant in any of the models run. Summary statistics for variables are presented in Panel A of Table A1.

The 1st statement said: "Private schools serve as competitors to public schools, enhancing quality of schooling." Table A3 presents different specifications in columns 1-3. Column (1) presents estimates for both genders combined. We find that public school teachers are more likely to disagree with the statement, reflecting their inherent biases and self-interest. Disagreement is lowest for individuals of about 50 years of age, who are more likely to have had recent experience with state schools either as students or parents. Non-state schools are also more likely to be seen as providing competition by informed parents and parents of a child in a non-state school who find local school choices satisfactory. Disagreement with the statement is more likely among parents who do not find local school choice satisfactory and report their child being at public school. Interestingly, education and being a teacher in a private school do not affect the opinion. In columns (2) and (3) we report results for men and women run separately. Interestingly, none of the parameters is significant in the men's model while estimates for women are, therefore, very similar to the aggregate model in column 1. This suggests that Czech men do not extensively participate in their children's education and schooling, leaving these decisions, as well as active involvement, to their wives.

The second statement said: "Private schools are accessible mainly to the rich". We use the same set of explanatory variables as for the first statement. Estimated parameters are presented in column (4). Only three factors appear to be significant (at 10\%). Teachers in private schools are more likely to disagree with this perception, suggesting that the general public may not have an accurate perception about the reality of (low) costs. More educated and younger individuals are more likely to agree with this statement. Earnings, however, do not play a role in 
creating this perception.

The third statement says: "Private schools are mostly of better quality than public ones." The parameter estimates are reported in column (6). Agreement with this statement is largely determined by how well the person is informed. Teachers and more educated individuals are more likely to disagree. Only parents who are satisfied with local private schools are more likely to support this statement. We suspect that the informed opinion is in general accurate, and that many non-public schools have found their niche by accepting students denied admission to oversubscribed public schools that are unable to meet demand for places. Once again, all such opinions are found in estimates for women.

The fourth statement said: "Private schools have the right to get the same funding per student as public schools are getting". Estimated parameters are presented in column (5). We find that two minor groups are significantly more likely to support this statement: teachers in private schools and parents who find the local choice of schools good and have a child in a nonstate school. These results, while not surprising, provide reassurance that the survey contains reliable opinions. Public school teachers, again reflecting their self-interest, are much more likely to disagree. Again results for men are not significant except that male teachers seem to be more likely to disagree with the statement. We conclude that the perception of the role of non-state schools depends strongly on the amount of information and experience the individual has with the whole school system. Incumbent state-school teachers express a negative attitude towards non-state schools, reflecting their vested interests. Similarly, those who work in such schools are generally supportive. We find strong evidence that the opinion of women on these issues is much stronger than that of men. 


\section{Parental school choice}

The second issue we look at is the decision to enroll a child in a non-state school. The data possess some limitations because there are only 661 persons who have a child in either a grammar or upper secondary school. ${ }^{6}$ To identify factors determining public/private school choice, we use a standard probit model. The set of explanatory variables used along with summary statistics is presented in panel B of Table A1. We do not use years of education of the person responding but rather the highest education between the two parents. We are forced, however, to include personal earnings because we do not have information on household income and wealth. These should, however, be highly correlated with the included measure. Thus, the measure we use should proxy for the actual determinant of school choice with error, introducing classical measurement bias towards zero in the estimates. The marginal probability effects are presented in Table A4, column (1). We find that teachers in public schools are less likely to place their child into a non-state school. On the other hand, teachers from non-state schools seem to be more likely to place their child into non-state schools (on the margin of $10 \%$ significance). Parents with higher earnings and families with more education are more likely to choose a nonstate school. Respondents with higher earnings are more likely to choose a non-state school. ${ }^{27}$ Our interpretation is that non-state schools absorb those students closed out of state schools. Educated parents are likely to see it as bad if their child does not go to a gymnazium. Therefore, they enroll him or her in a non-state gymnazium if a state gymnazium is not available (the student did not pass entrance exams). Less educated parents will simply send the child to a vocational/apprentice school.

\footnotetext{
${ }^{26}$ We also defined a smaller group of parents with children at secondary school only, but the results are not substantially different.

${ }^{27}$ Since earnings of men could have a greater role in the household budget, we also add an earnings interacted with
} 
The likelihood of a non-state school choice declines with diminishing rate with age and increases again beyond 43 years of age. At the same time, 28 percent of respondents reporting a a school age child are older than 43 years. 28

In column (2) we present a similar model that considers only parents who have a child in secondary school (the model in (1) considered also grammar school children but non-state grammar schools have very little enrollment). The results are similar although we should note that the limited number of observations available (222) does not allow us to identify the effect of non-state school-teachers.

Results suggest that those who are best informed about educational alternatives or who value education more highly are more likely to enroll their children in non-state schools. Given that one primary role of non-state schools is to provide an opportunity to those students excluded from top-level (academic) education due to lack of capacity in the public school system and consequent attempts to divert some students into vocational or technical tracks, this finding suggests that more educated and involved parents are more likely to resist such pressure on their desires for their children's futures. The finding that parents with greater incomes are more likely to opt for non-state schools calls for further research. Nevertheless, it is consistent with there being higher costs for such schools and with wealthier parents placing greater emphasis on their children's education. Determining which of these is key is critical for establishing public policy towards schooling alternatives.

GENDER dummy but find corresponding coefficient insignificant.

${ }^{28}$ Other variables were not significant: dummy if person finds local choice of schools poor, municipality-size dummies, marital status. 


\section{F. Factors Influencing the Establishment of Non-state Schools}

In this section and those that follow we focus on the Czech Republic, first examining academic high schools (gymnázia) and then technical high schools. The reasons for examining the Czech Republic are straightforward. We will rely on district level data for much of our analysis and the larger number of Czech districts makes econometric work more practical.

\section{Academic High Schools}

Table 7 shows the distribution of the number of state and non-state gymnázia by district for 1992, 1995 and 1999. The most important characteristic is that there is considerable variation in the presence of non-state gymnázia. Many districts have no non-state alternative to the state academic high school(s). We are interested in what factors determine whether a nonstate gymnázium is founded in a given district. In particular, is it the case that such schools arise when the state alternative is, in some sense, less attractive?

We are particularly interested in whether the quality of the public gymnázia in regions affected the probability of a private or church-supported gymnázium being established. We have a direct measure of the quality of the public gymnázia in a district based on the success of their graduates in obtaining admission to university. In this context it should be recalled that the primary purpose of gymnázia is to prepare students for university admission and that the vast majority of gymnázia graduates seek to go on to tertiary education, although many applications for admission are not successful. For each school the statistical institute of the Ministry of Education has calculated a measure of the success of applicants from that school in obtaining university admission. This measure is the ratio of applications accepted to applications filed for students from the school. Given that students seeking university admission apply to approximately 2.5 schools on average, each student is counted more than once. In addition, the measure we used weights each observation by the ratio of total applications to total admissions for the university in question, thereby placing more weight to the better universities in the 
country. ${ }^{29}$

It is not appropriate, however, to measure the quality of a school by the raw success of its graduates in obtaining university admission. Some schools will start with more advantaged students who may have a high success rate even if the school is actually performing poorly. Other schools may be exceptional performers in that they produce high value-added even if the overall success rate of their students is not particularly high due to poor inputs (especially entering-student quality). We therefore measure quality by a school's performance relative to how well it would be expected to do based on its environment. In the first stage we estimate a school's success rate as a function of the share of the local population with at least a secondary school maturita-level education, share of the population living in towns (as opposed to villages), average class size in primary schools in the district (on the assumption that this will be reflected in the average quality of students arriving in the local gymnázia) and grade average of applicants to the gymnázium from primary school (again to reflect quality of incoming students). For each public gymnázium we calculate the residual from a regression equation predicting success in university admissions. We then average these residuals (weighted by school size) for all public gymnázia in a districtand use this district average residual as a measure of public-school-quality in each local market. ${ }^{30}$ We use this public school quality measure together with other explanatory variables in the second stage model of non-state school entry.

Table 8a reports descriptive statistics on explanatory variables considered in the first and second stage regressions. The first stage OLS regression results are presented in Table $8 \mathrm{~b}$. The

\footnotetext{
${ }^{29}$ Although there are approximately 23 universities in the Czech Republic, there are widely perceived quality differences among them. By general consensus, three institutions (Charles University and the Czech Technical University in Prague and Masaryk University in Brno) are regarded as significantly better than other alternatives and attract substantial excess demand every year. The technical success measure used is defined as: $z_{j}=\sum_{i}\left(k_{i} * x_{i, j} / y_{j}\right)$ where $k_{j}=$ applications/admissions for university "i"; $x_{i, j}=$ number of applicants admitted to university "i” from gymnázium “ $\mathrm{j}$ ”; and $y_{j}=$ total number of applications to all universities from gymnázium “j.”

${ }^{30}$ Although derived independently (see Technical appendix), the methodology used to assess school quality is similar to that devised by NORC at the University of Chicago for a recent survey of high school quality in the US (U.S. News, 1999).
} 
results of second stage probit regression are presented in Table 8c. The dependent variable takes the value of one if a non-state gymnázium had been established in a district by $1995 .{ }^{31}$ Several factors appear to be associated with whether a non-state gymnázium was established including the education level of the population, the population density, and the relative size of the secondary-school-aged population. The positive relationship between a district's unemployment rate and the presence of a non-state gymnázium may reflect dissatisfaction with the performance of the public school system if recent graduates from that system are having a hard time finding a job. ${ }^{32}$ The last factor may be particularly relevant if a large student population increases admissions pressure on a relatively fixed supply of public gymnázium places. ${ }^{33}$ In addition to those reported in Table 8c, we analyzed a number of other factors that might be related to the establishment of non-state schools. These include the share of votes for the ruling coalition parties (on the grounds that regions that supported the government might have received favorable capital investment treatment in the public system), average wages in the district, share of employment in agriculture, and distance from a major urban area. None had a significant effect, so they have not been included in the estimates reported.

As can be seen in Table 8c, the effect of public gymnázia quality on whether or not a non-state gymnázium is established is significant and negative. If public schools in an area do better than expected in getting their graduates into university, it is less likely that non-state competitors will emerge. Evaluated at mean levels, a one standard-deviation increase in the success of public gymnázia in a district results in approximately a one-third reduction in the probability of a non-state gymnázium being established in that district.

\footnotetext{
${ }^{31}$ As we saw earlier, there has been little change in the extent of non-state schools since 1995 in the Czech Republic.

${ }^{32}$ In the early years of the decade the overall unemployment rate in the Czech Republic was quite low, especially for a transition economy, averaging under 4 percent. Some districts, however, had unemployment rates that approached 10 percent. In recent years the overall rate has risen to slightly under 10 percent with the rate in some districts exceeding 20 percent.

${ }^{33}$ While operational funding increases with enrolled students, the physical capital stock may well have been capacity constrained (or at least limited, such that a large cohort would result in larger classes, making the public institution less attractive).
} 
There are two issues of simultaneity that might bias our results. The earliest data we have available for measuring admission success come from the 1995/96 academic year. Thus, we are using a measure of success after the establishment of non-state schools to predict their establishment. While it would obviously be preferable to use admission success from 1992 or earlier, before there were a significant number of non-state schools, it is likely that any biases introduced by the use of later data will work against the effect we see, thereby strengthening our results. We say this for two reasons. As we will discuss below, there is at least preliminary evidence that state gymnázia respond to the challenge of non-state competition by improving quality. To the extent that some such improvement has already taken place by the time we measure public-school quality, the quality differences between districts where non-state schools came into existence and those where they did not should have been even greater at the time the non-state schools were established. Furthermore, non-state gymnázia typically draw from the lower end of the quality distribution among potential applicants. ${ }^{34}$ Thus, where non-state gymnázia exist, there should be a selectivity effect increasing the average quality of students remaining in the public system, again serving to reduce differences from the time when the nonstate schools were established.

There is a hypothetical problem with our measure of university admission success. Since students typically apply for more than one university, number of applications could be correlated with school quality. Positive correlation could emerge if better school management motivates students to apply for more universities, increasing the likelihood of school admission.

\section{Technical Schools}

The role of secondary technical schools is quite different from that of gymnázia. Technical schools are expected to provide education that directly affects the labor market

\footnotetext{
${ }^{34}$ As a rough measure, the grade average of elementary school students entering state gymnázia in 1995 was 1.30 (where 1 is the best grade and 5 is the worst), while the average for those entering non-state gymnázia was 1.5. Lower quality students typically being drawn by private gymnázia has been confirmed by many experts we discussed this issue with.
} 
productivity of graduates, instead of preparing them for successful enrollment in university. The proportion of technical school graduates who apply to universities is much smaller the proportion from gymnázia while differences in the proportions admitted are even more pronounced. Thus the admission rate to university is not a proper indicator of technical school quality. Moreover, the curricula provided by technical schools is heterogeneous by definition. Although there have been some attempts to shrink the number of fields of study, hundreds of different curricula remain at the end of the $1990 \mathrm{~s} .{ }^{35}$

As discussed above, regional mobility of the labor force in the Czech Republic is extremely low, with what mobility that exists arising mainly because of marriages. This implies that regions are to a large extent local markets and there should be a close relationship between the education provided and the prevailing industrial/occupational structure at the regional level. On the other hand, when disruptions due to the transition result in a mismatch between the educational institutions in a given region and that region's current labor market needs, there will be little possibility of resolving this mismatch through mobility of workers trained in other regions.

We would expect private vocational schools to be more responsive to local labor market conditions and to arise when there are obvious niches to be filled in the demand for education. To test this hypothesis we consider a simple linear model

$$
S_{j, d}^{I}=\beta D_{j, d}+\varepsilon_{j, d}
$$

where $S$ represents an education supply indicator, $D$ represents a vector of determinants of local demand for education, $\exists$ is a vector of parameters, $\varepsilon$ is a stochastic error term, and the subscripts $j$ and $d$ identify vocational branch and region. As in the case of gymnázia, public-school quality should be an important determinant of whether private schools arise. Since, however, we cannot

\footnotetext{
${ }^{35}$ Personal conversations have revealed that there are approximately fifteen people at the Czech Ministry of Education, each of whom supervising a set each vocational fields. The number of fields within a given general branch depends on the belief of the individual in charge of that branch, with new fields proposed by schools being approved or rejected based on personal opinion. This has resulted, for example, in many, highly-specialized fields in the Electronics branch but few in the Engineering branch.
} 
rely on admission rates to universities, we focus instead on returns from education as the major determinant of school choice and demand for individual vocational branches. Our hypothesis is that the likelihood that a private school with a given vocational specialization is established in a region depends positively on the relative scarcity of labor of a particular type in the region.

To obtain a proxy for the unmet demands of the market economy, we look at where workers are earning more than they would be predicted to earn based on their age, sex, etc. In particular, we use the residual from a standard Mincerian wage equation as a measure of "extraordinary" earnings. ${ }^{36}$ The indicator is

$$
\Delta w_{j, d}=w_{j, d}^{96}+w_{j, d}^{89}
$$

where $w$ represents average residual from an economy-wide log wage equation for individuals with secondary-school vocational education (and the maturita exam) falling in a given region/vocational branch specific cell. This equation was estimated using a representative survey of about 3500 workers that asked retrospective wage histories for the period 1989-1996 (see Munich et al., 1999, for a description of this data). ${ }^{37}$ Averages are taken across 17 vocational fields and 8 regions (including Prague). ${ }^{38}$

We would also expect that the likelihood of a private school being established is greater in regions where there is significant unemployment, thereby indicating that current schools are not providing appropriate training. Unemployment rate is therefore included on the right-hand

\footnotetext{
${ }^{36}$ In fact, given the likelihood of unmeasured job characteristics that resulted in higher wages for industries such as mining even under communism, we use the change in this residual between 1989, when wages did not reflect market shortages, and 1996 when they presumably did.

${ }^{37}$ The Czech Labor Force Survey does not collect wage information and there is no other data source such as household budget surveys or micro-censuses that provides information on wages for both the pre- and post-transition periods by branches.

${ }^{38}$ Educational data distinguish 31 vocational branches. These vocational branches are not identical with occupational data from the retrospective survey. Therefore, for each two-digit occupational code we identified the closest matching vocational branch. We merged several vocational groups if they fell within a single occupational group (examples include Architecture-Urbanism and Construction-Geodesy-Cartography, Health and Veterinary, Chemistry and Technical Chemistry, Trade and Law). We also excluded a few vocational branches from our analysis when they were too divorced from market operations (such as theology) to estimate reliable wage equations.
} 
side of our estimating equations as well as dummies for Prague and for the Finance and Business vocational branch.

Although we have 136 possible observations (17 fields times 8 regions), we are constrained by the number of observations available in the Retrospective survey. For some field/region cells we do not have a sufficient number of individuals to estimate reliable wage equations. We have excluded cells with fewer than 5 observations, leaving us 91 observation units. Increasing this threshold has only a minor impact on results.

We have examined two indicators of the responsiveness of private schools to labor market conditions. The first considers the ratio of private school to public school enrollment in a given region and vocational branch. The second is the ratio of private school enrollment in a given region and vocational branch to total regional enrollment in vocational schools, both private and public, across all vocational branches. Finally, for comparison purposes, we examine the growth rate of public vocational school enrollment in a given field/region cell to see if these schools also respond to labor market conditions.

Regression results for alternative supply of education indicators are presented in Table 9. Since many region/field cells do not have any private school enrollment, estimates for the extent of private school enrollment are of the truncated regression (TOBIT) form, while the growth in public school enrollment is estimated using ordinary least squares (OLS).

Results are quite clear. Both public and private technical schools have responded to market demands in that they have increased their provision for training in financial and business subjects. Here, however, the similarity ends. Non-state schools have created opportunities for training in areas and fields where wages have been growing most rapidly, indicating increasing demand, and where unemployment rates are highest, indicating greater regional mismatch of workers and jobs. Public technical schools, on the other hand, exhibit no such market response. In fact, the signs on the rate of wage growth and local unemployment rates are negative, although insignificant.

This pattern makes sense. As we saw earlier, returns to technical education increased the 
most during the post-communist period. It is likely that pre-existing state technical schools provided training better suited to the old industrial structure, thereby leaving gaps in the curricula demanded by employers in the emerging market economy that were filled by newly created nonstate schools. Thus, unbound by past investments in physical and human capital, non-state schools have concentrated in high-demand areas such as commerce, economics and hotel management. State schools, on the other hand, have not been able to keep up with shifting market demands. Thus, our results are consistent with recent reports that the unemployment rate of graduates from non-state secondary schools is lower than that of graduates from public schools (UIV, 2000).

\section{G. The Role of Non-state Schools in Promoting Reform of State Schools}

Finally, we turn to the issue of how state schools respond when confronted with competition from non-state schools. Here our evidence is limited by data availability and comes only from a study of gymnázia in the Czech Republic. We divided the 77 districts into three groups according to the fraction of newly enrolled students entering non-state gymnázia in 1995. Public gymnázia in 44 districts faced no competition from non-state alternatives, while in another 7 districts newly established private gymnázia were of the extended format and enrolling students only in the lower grades in 1995. This left 26 districts where there was significant competition. These were divided into two groups: those where less than 20 percent of new enrollees in gymnázia opted for non-state schools and those where this percentage was greater than $20 .{ }^{39}$ Table 10 shows that there were small, but perhaps meaningful, differences in how state schools behaved depending on the degree of competition they faced from private alternatives. Between 1996 and 1998 state gymnázia in districts where there was no private competition increased the number of personal computers per pupil by 533 percent and reduced

\footnotetext{
${ }^{39}$ Nationwide approximately 12 percent of new entrants to gymnázia in 1995 enrolled in non-state schools. Because there were no non-state schools in the majority of districts, the percentage opting for such schools where they were available was significantly higher.
} 
average class size by 1.8 percent. State gymnázia in districts facing the greatest competition increased the PC/pupil ratio by 683 percent and reduced class sizes by 3.4 percent. Given that the fraction of students in non-state schools actually shrank over this period, it is unlikely that these changes were due to mechanical effects from students leaving the public system. Rather they appear to be real differences in behavior designed to make the public gymnázia more attractive.

Perhaps the greatest difference can be seen in what we have argued is the true test of the performance of gymnázia, success in gaining university admission for graduates. If we rank districts from 1 to 77 according to the success of graduates from their state gymnázia in obtaining university admission, public gymnázia facing significant competition improved their relative rank by 4.47 positions between 1996 and 1998, while those facing moderate competition improved their ranking by an average of 0.55 positions. Given that there are a fixed number of districts, these improvements came at the expense of state gymnázia in districts where there was no competition from non-state alternatives. State gymnázia in these districts saw their relative position deteriorate by an average of 1.43 positions.

\section{H. Summary and Conclusions}

Post-communist Central Europe provides an interesting laboratory in which to investigate possible responses were a relatively large U.S. state to adopt universal education vouchers. Although public schools were initially relatively good by objective standards, there was an initial surge in initial demand for private alternatives that eventually reached between 10 and 15 percent of the secondary school population. Private schools appear to have arisen in response to distinct market incentives. They are more common in fields where public school inertia has resulted in an under-supply of available slots. They are also more common where the public schools appear to be doing a worse job in their primary educational mission, as seen by the success rate of academic high schools in obtaining admission to the top universities for their graduates.

There is also preliminary evidence that public schools facing private competition do 
improve their performance. While the evidence is modest with respect to inputs, in the Czech Republic public academic high schools facing significant private competition in 1995 improved their relative success in obtaining university admissions for their graduates by over four positions (out of 77) between 1996 and 1998.

Of course these results are at best preliminary and generalizations must be made with caution. Private schools arose in the Czech Republic and Hungary at a time of great turmoil in the educational system and the society in general. There has been a limited time over which to observe the responses of public schools. In summary, however, the preliminary evidence from the adoption of a nation wide voucher scheme among the countries of Central Europe, especially the Czech Republic, supports the claims of advocates for such systems. Private schools supported by vouchers increase educational opportunity and spur public schools to improved performance. 


\section{References}

Andrle, Alois (1998) "Economic Transformation and Job-related Migration in the Czech Republic during 1992-1996, Statistika, No.5, Prague: Czech Statistical Office.

Aradi, Zsolt, Gábor Halász and Jdit D. Nagi (1998) "Reforms in Education Financing” in Lajos Bokros and Jean-Jacques Dethier, eds. Public Finance Reform during the Transition: The Experience of Hungary, Washington, D.C.: The World Bank.

CEPR (1998), Mediating the Transition: Labour Markets in Central and Eastern Europe, London: Centre for Economic Policy Research, Forum Report of the Economic Policy Initiative.

Chase, Robert S. (1998) "Markets for Communist Human Capital: Returns to Education and Experience in Post-Communist Czech Republic and Slovakia," Industrial and Labor Relations Review, 51:3, pp. 401-23.

Erbenová, Michaela (1997) "Essays on Disequilibria in Early Transition," Unpublished Ph.D. Dissertation, Prague: CERGE-EI.

European Commission (1999) Key Data on Education in Europe, Luxembourg: Eurostat.

European Training Foundation (1999) Vocational Education and Training in Central and Eastern Europe: Key Indicators, Luxembourg: Office for Official Publication of the European Communities.

Filer, Randall K. and Jan Hanousek (2000) "Output Changes and Inflationary Bias in Transition,” Prague: CERGE-EI Discussion Paper \# 14/98.

Filer, Randall K, Štロpán Jurajda, and Ján Plánovský (1999) "Education and Wages in the Czech and Slovak Republics During Transition,” Labour Economics 6:4, pp. 581-93.

(1998), "Returns to the Market: Valuing Human Capital in the Post-Transition Czech and Slovak Republics," Prague, CERGE-EI Working Paper \# 125.

Institute for Information on Education (UIV), Ministry of Education, Youth and Sport in the Czech Republic, 1999 ,Skolstvi na krizovatce," UIV, Praha, ISBN 80-211-0305-1.

Institute for Information on Education (UIV), Ministry of Education, Youth and Sport in the Czech Republic (1999) Vyvojova rocenka: skolstvi v Ceske republice 1989/90 - 1998/99 (Annual Trends: The School System in the Czech Republic 1989/90 - 1998/99), Prague: UIV.

Institute for Information on Education (UIV), Ministry of Education, Youth and Sport in the Czech Republic (2000), "Co potrebuji absolventi pro uplatneni na trhu prace," UIV, 
VUOS, CSVS, forthcoming.

Keune, Maarten (1998) "Youth Unemployment in Hungary and Poland" Geneva: International Labour Organization Employment and Training Paper \#20.

Laporte, Bruno and Julian Schweitzer (1994) 'Education and Training.' In Nicholas Barr (ed) Labor Markets and Social Policy in Central and Eastern Europe: The Transition and Beyond. Oxford: Oxford University Press for the World Bank and the LSE.

Laporte, Bruno and Dena Ringold (1997) Trends in Education Access and Financing during the Transition in Central and Eastern Europe,Technical Paper No. 361 Washington, D.C.: The World Bank.

Micklewright, John (1999) “Education, Inequality and Transition," Economics of Transition 7:4, pp. 343-376.

Munich, Daniel, Jan Svejnar, and Katherine Terrell (1999) "Returns to Human Capital Under the Communist Wage Grid and During the Transition to a Market Economy." Prague: CERGE-EI Discussion Paper \#29/99.

OECD (1997) Education at a Glance Paris: Organization for Economic Cooperation and Development.

Paihle, Ariane (1998) "La hausse des inégalités salariales en Europe centrale au cours de la transition," Economie Internationale 75: 3, pp. 105-133.

Svejnar, Jan (1999) "Labor Markets in the Transitional Economies of Central and Eastern Europe," in Orley Ashenfelter and Richard Layard, eds. Handbook or Labor Economics, Vol 3B Amsterdam: North Holland.

Tomášek, V., J. Straková, and J. PaleDková (1997) “TDetí mezinárodni výzkum matematického a pDírodovDdného vzdDláváni," ("TIMSS International Rankings of Education in Mathematics and the Natural Sciences"), Prague: UIV.

U.S. News and World Report, (1999) "Outstanding High Schools,” January 18, 1999.

Varga, J. (1995) "Returns to Education in Hungary,” Acta Oeconomica 47: 1-2, pp. 203-214.

Várhegyi, György (1996) Independent Schools in Hungary, Budapest: The Association of Hungarian Foundation and Private Schools. 
Table 1

Fraction of Primary and Secondary School Students in Non-state Schools - 1996/97

\begin{tabular}{|l|c|}
\hline Country & $\begin{array}{c}\text { \% in Non-state } \\
\text { Schools }\end{array}$ \\
\hline Central Europe & $0.5 \%$ \\
\hline Bulgaria & $5.0 \%$ \\
\hline Czech Republic & $1.3 \%$ \\
\hline Estonia & $0.7 \%$ \\
\hline Latvia & $0.2 \%$ \\
\hline Lithuania & $4.6 \%$ \\
\hline Hungary & $2.0 \%$ \\
\hline Poland & $0.9 \%$ \\
\hline Romania & $0.4 \%$ \\
\hline Slovenia & $4.6 \%$ \\
\hline Slovakia & $7.4 \%$ \\
\hline EU Comparison Countries & $58.8 \%$ \\
\hline Austria & $20.6 \%$ \\
\hline Belgium & $4.7 \%$ \\
\hline France & $5.7 \%$ \\
\hline Germany & $15.7 \%$ \\
\hline Italy & \\
\hline Netherlands & $77.1 \%$ \\
\hline United Kingdom & \\
\hline EU Average & \\
\hline & \\
\hline
\end{tabular}

Source: European Commission (1999) 
Table 2

Age Structure of the School-Aged Population

(thousands)

\begin{tabular}{|l|c|c|c|c|c|c|c|c|c|c|c|}
\hline \multicolumn{1}{|c|}{ Age } & $\mathbf{7}$ & $\mathbf{8}$ & $\mathbf{9}$ & $\mathbf{1 0}$ & $\mathbf{1 1}$ & $\mathbf{1 2}$ & $\mathbf{1 3}$ & $\mathbf{1 4}$ & $\mathbf{1 5}$ & $\mathbf{1 6}$ & $\mathbf{1 7}$ \\
\hline Czech Republic & & & & & & & & & & & \\
\hline \# of Children 1991 & 133.9 & 134.5 & 138.6 & 141.1 & 150.4 & 168.0 & 174.0 & 177.2 & 182.0 & 187.0 & 188.6 \\
\hline \# of Children 1999 & 120.8 & 128.5 & 127.7 & 125.9 & 129.8 & 128.2 & 130.6 & 133.4 & 134.0 & 134.5 & 138.7 \\
\hline Hungary & & & & & & & & & & & \\
\hline \# of Children 1991 & 123.0 & 129.3 & 138.1 & 143.7 & 154.6 & 162.9 & 170.0 & 178.0 & 189.4 & 181.1 & 150.7 \\
\hline \# of Children 1999 & 124.9 & 123.4 & 120.7 & 121.5 & 122.9 & 124.2 & 126.1 & 120.8 & 122.9 & 129.1 & 137.9 \\
\hline Poland & & & & & & & & & & & \\
\hline \# of Children 1991 & 679.5 & 696.6 & 680.0 & 651.3 & 665.7 & 656.2 & 644.6 & 631.2 & 638.8 & 623.1 & 599.6 \\
\hline \# of Children 1999 & 505.2 & 536.4 & 535.3 & 551.6 & 574.9 & 590.3 & 617.7 & 657.8 & 679.5 & 696.6 & 680.0 \\
\hline
\end{tabular}

Source: National Statistical Yearbooks, Various Years. 
Table 3

Public Expenditures on Education

\begin{tabular}{|c|c|c|c|c|c|c|c|c|c|c|}
\hline & 1989 & 1990 & 1991 & 1992 & 1993 & 1994 & 1995 & 1996 & 1997 & 1998 \\
\hline \multicolumn{11}{|l|}{ Czech Republic } \\
\hline Billions of 1989 crowns* & 21.7 & 21.4 & 18.1 & 20.1 & 23.3 & 24.9 & 26.0 & 27.2 & 24.2 & 22.2 \\
\hline 1989 Crowns per Student & 8,870 & 9,050 & 7,960 & 8,990 & 10,490 & 11,100 & 11,590 & 12,190 & 10,970 & 10,260 \\
\hline As Share of GDP & $4.0 \%$ & $4.1 \%$ & $4.1 \%$ & $4.5 \%$ & $5.3 \%$ & $5.3 \%$ & $5.2 \%$ & $5.2 \%$ & $4.7 \%$ & $4.4 \%$ \\
\hline \multicolumn{11}{|l|}{ Hungary } \\
\hline Billions of 1989 Florints* & 86.9 & 94.8 & 82.4 & 91.6 & 88.4 & 89.4 & 77.4 & 69.1 & 73.0 & 74.0 \\
\hline 1989 Florints per Student & 39,600 & 44,100 & 38,700 & 43,500 & 42,500 & 43,400 & 37,400 & 33,400 & 35,500 & 36,100 \\
\hline As Share of GDP & $5.0 \%$ & $5.9 \%$ & $5.7 \%$ & $6.7 \%$ & $6.5 \%$ & $6.4 \%$ & $5.5 \%$ & $4.9 \%$ & $5.0 \%$ & $4.9 \%$ \\
\hline
\end{tabular}

Source: Authors' calculations based on National Statistical Yearbooks, Various Years 
Table 4

Increased Earnings Compared to Primary School Graduates Over Time in the Czech Republic

\begin{tabular}{|c|c|c|c|c|}
\hline Level of Education & $\mathbf{1 9 8 4}$ & $\mathbf{1 9 9 3}$ & $\mathbf{1 9 9 5}$ & $\mathbf{1 9 9 7}$ \\
\hline Academic HS & $15 \%$ & $27 \%$ & $35 \%$ & $52 \%$ \\
\hline Technical HS & $20 \%$ & $28 \%$ & $45 \%$ & $57 \%$ \\
\hline Vocational HS & n.a. & n.a. & $31 \%$ & $37 \%$ \\
\hline University & $40 \%$ & $60 \%$ & $92 \%$ & $125 \%$ \\
\hline
\end{tabular}

Figures for 1984 and 1993 calculated from Chase (1998)

Figures for 1995 and 1997 from Filer, Jurajda and Plánovský (1999) 
Table 5a

Secondary Schools by Type, 1989-1998 - Czech Republic

\begin{tabular}{|c|c|c|c|c|c|c|c|c|c|c|c|}
\hline & & $89 / 90$ & 90/91 & 91/92 & 92/93 & 93/94 & 94/95 & $95 / 96$ & 96/97 & 97/98 & 98/99 \\
\hline \multicolumn{12}{|l|}{ Academic } \\
\hline & State & 225 & 227 & 234 & 244 & 262 & 276 & 282 & 283 & 284 & 277 \\
\hline & Non-state & 0 & 2 & 24 & 41 & 62 & 72 & 79 & 84 & 82 & 79 \\
\hline \multicolumn{12}{|l|}{ Technical } \\
\hline & State & 375 & 390 & 564 & 575 & 598 & 677 & 711 & 668 & 653 & 626 \\
\hline & Non-state & 0 & 4 & 57 & 133 & 222 & 294 & 314 & 333 & 297 & 260 \\
\hline \multicolumn{12}{|l|}{ Vocational } \\
\hline & State & 646 & 671 & 663 & 669 & 643 & 638 & 625 & 611 & 574 & 508 \\
\hline & Non-state & 0 & 0 & 27 & 34 & 84 & 93 & 105 & 127 & 117 & 109 \\
\hline \multicolumn{12}{|l|}{ Total } \\
\hline & State & 1246 & 1288 & 1461 & 1488 & 1503 & 1591 & 1618 & 1562 & 1511 & 1411 \\
\hline & Non-state & 0 & 6 & 108 & 208 & 368 & 459 & 498 & 544 & 496 & 448 \\
\hline & $\%$ Non-state & 0 & 0.5 & 6.9 & 12.3 & 19.7 & 22.4 & 23.5 & 25.8 & 24.7 & 24.1 \\
\hline
\end{tabular}


Table 5b

Secondary Schools by Type, 1989-1998 - Hungary

\begin{tabular}{|c|c|c|c|c|c|c|c|c|c|c|c|}
\hline & & $89 / 90$ & 90/91 & 91/92 & 92/93 & 93/94 & 94/95 & 95/96 & 96/97 & $97 / 98$ & 98/99 \\
\hline \multicolumn{12}{|l|}{$\begin{array}{l}\text { Academic + } \\
\text { Technical* }\end{array}$} \\
\hline & State & 665 & 717 & 747 & 772 & 801 & 809 & 832 & 845 & 840 & 855 \\
\hline & Non-state & $10 * *$ & $10^{*}$ & 33 & 52 & 65 & 78 & 104 & 135 & 149 & 181 \\
\hline \multicolumn{12}{|l|}{$\begin{array}{l}\text { Vocational + } \\
\text { 2-Year }\end{array}$} \\
\hline & State & 391 & 417 & 526 & 620 & 632 & 618 & 599 & 553 & 497 & 452 \\
\hline & Non-state & 0 & 0 & 8 & 24 & 28 & 34 & 43 & 52 & 51 & 57 \\
\hline \multicolumn{12}{|l|}{ Total } \\
\hline & State & 1056 & 1134 & 1273 & 1392 & 1433 & 1427 & 1431 & 1398 & 1337 & 1307 \\
\hline & Non-state & 10 & 10 & 41 & 76 & 93 & 112 & 147 & 187 & 200 & 238 \\
\hline & $\begin{array}{l}\text { \% Non- } \\
\text { state }\end{array}$ & $0.9 \%$ & $0.9 \%$ & $3.7 \%$ & $5.2 \%$ & $6.1 \%$ & $7.3 \%$ & $9.3 \%$ & $11.8 \%$ & $13.0 \%$ & $15.4 \%$ \\
\hline
\end{tabular}

* Available data does not allow separate identification of academic and technical high schools.

** Estimated from unofficial sources 
Table 6a

Enrollment in Secondary Schools by Type, 1989-98 - Czech Republic

(thousands)

\begin{tabular}{|c|c|c|c|c|c|c|c|c|c|c|c|}
\hline & & $89 / 90$ & 90/91 & 91/92 & $92 / 93$ & 93/94 & $94 / 95$ & 95/96 & 96/97 & 97/98 & 98/99 \\
\hline \multicolumn{12}{|l|}{ Academic } \\
\hline & State & 100.7 & 101.8 & 95.9 & 89.9 & 80.5 & 76.6 & 77.1 & 66.8 & 66.3 & 68.4 \\
\hline & Non-state & 0 & 0.1 . & 0.9 & 3.5 & 5.8 & 8.4 & 9.2 & 8.3 & 7.9 & 7.4 \\
\hline \multicolumn{12}{|l|}{ Technical } \\
\hline & State & 158.7 & 166.6 & 170.4 & 171.7 & 176.5 & 188.8 & 195.3 & 151.4 & 152.7 & 149.7 \\
\hline & Non-state & 0 & 0.2 & 4.6 & 15.5 & 30.4 & 44.7 & 50.5 & 37.7 & 31.8 & 25.5 \\
\hline \multicolumn{12}{|l|}{ Vocational } \\
\hline & State & 310.2 & 301.8 & 278.6 & 250.8 & 241.2 & 242.6 & 234.7 & 178.6 & 156.8 & 132.9 \\
\hline & Non-state & 0 & 0 & 0 & 17.4 & 27.5 & 26.0 & 27.3 & 21.5 & 19.3 & 17.5 \\
\hline \multicolumn{12}{|l|}{ Total } \\
\hline & State & 569.8 & 570.2 & 544.9 & 510.4 & 498.2 & 508.0 & 507.1 & 396.8 & 375.8 & 350.9 \\
\hline & Non-state & 0 & 0.3 & 5.5 & 36.4 & 63.7 & 79.1 & 87.0 & 67.5 & 59.0 & 50.4 \\
\hline & $\%$ Non-state & 0 & 0 & 1.0 & 6.7 & 11.3 & 13.5 & 14.6 & 14.5 & 13.6 & 12.6 \\
\hline
\end{tabular}


Table 6b

Enrollment in Secondary Schools by Type, 1989-98 - Hungary

(thousands)

\begin{tabular}{|l|l|c|c|c|c|c|c|c|c|c|}
\hline & & $\mathbf{8 9 / 9 0}$ & $\mathbf{9 0 / 9 1}$ & $\mathbf{9 2 / 9 3}$ & $\mathbf{9 3 / 9 4}$ & $\mathbf{9 4 / 9 5}$ & $\mathbf{9 5 / 9 6}$ & $\mathbf{9 6 / 9 7}$ & $\mathbf{9 7 / 9 8}$ & $\mathbf{9 8 / 9 9}$ \\
\hline Academic & & & & & & & & & \\
\hline & State & 112.7 & 118.3 & 127.8 & 127.2 & 127.1 & 124.8 & 123.1 & 121.9 & 121.6 \\
\hline & Non-state & 3.6 & 5.1 & 10.0 & 12.5 & 15.4 & 16.1 & 17.8 & 19.4 & 20.6 \\
\hline & & & & & & & & & & \\
\hline & State & 157.2 & 168.4 & 182.9 & 186.8 & 188.6 & 198.7 & 208.7 & 213.4 & 217.4 \\
\hline & Non-state & 0 & 0 & 2.2 & 4.0 & 6.3 & 9.7 & 11.8 & 13.8 & 17.0 \\
\hline & & & & & & & & & & \\
\hline Tocational & State & 222.2 & 222.2 & 209.6 & 196.2 & 181.9 & 168.5 & 151.1 & 138.1 & 121.5 \\
\hline & Non-state & 0 & 0 & 2.2 & 2.6 & 3.8 & 4.1 & 4.9 & 5.8 & 6.7 \\
\hline & & & & & & & & & & 4 \\
\hline & State & 492.1 & 514.0 & 520.3 & 510.2 & 497.6 & 492.0 & 482.9 & 473.4 & 460.5 \\
\hline & Non-state & 3.6 & 5.1 & 14.4 & 19.1 & 25.5 & 29.9 & 34.5 & 39.0 & 44.3 \\
\hline
\end{tabular}


Table 7

Distribution of the Number of Academic High Schools by District Czech Republic

\begin{tabular}{|c|c|c|c|c|c|c|}
\hline \multirow{2}{*}{$\begin{array}{c}\text { Number of } \\
\text { Gymnázia } \\
\text { in a District }\end{array}$} & \multicolumn{6}{|c|}{ Number of districts with given number of gymnázia } \\
\cline { 2 - 7 } & $\mathbf{1 9 9 2}$ & $\mathbf{1 9 9 5}$ & $\mathbf{1 9 9 9}$ & $\mathbf{1 9 9 2}$ & $\mathbf{1 9 9 5}$ & $\mathbf{1 9 9 9}$ \\
\hline $\mathbf{0}$ & 2 & 59 & 1 & 44 & 1 & State \\
\hline $\mathbf{1}$ & 5 & 12 & 5 & 16 & 6 & 20 \\
\hline $\mathbf{2}$ & 29 & 2 & 23 & 11 & 24 & 9 \\
\hline $\mathbf{3}$ & 22 & 2 & 21 & 2 & 23 & 0 \\
\hline $\mathbf{4}$ & 11 & 0 & 13 & 1 & 8 & 1 \\
\hline $\mathbf{5}$ & 2 & 0 & 6 & 0 & 7 & 0 \\
\hline $\mathbf{6}$ & 2 & 1 & 2 & 0 & 4 & 0 \\
\hline $\mathbf{7}$ & 1 & 0 & 2 & 0 & 1 & 0 \\
\hline $\mathbf{8}$ & 2 & 0 & 0 & 0 & 0 & 0 \\
\hline $\mathbf{9}$ & 0 & 0 & 1 & 1 & 1 & 0 \\
\hline $\mathbf{1 0}$ or More & 1 & 1 & 2 & 1 & 2 & 2 \\
\hline Total & $\mathbf{7 7}$ & $\mathbf{7 7}$ & $\mathbf{7 7}$ & $\mathbf{7 7}$ & $\mathbf{7 7}$ & $\mathbf{7 7}$ \\
\hline
\end{tabular}


Table 8a

Descriptive statistics

\begin{tabular}{|l|c|c|c|c|}
\hline 1st stage & mean & std.dev. & min & max \\
\hline$q$ & 97.220 & 25.253 & 4.60 & 170.52 \\
\hline Edu23 & 0.27 & 0.035 & 0.21 & 0.40 \\
\hline Townpop & 0.64 & 0.158 & 0.34 & 1.00 \\
\hline Pclass & 23.20 & 8.100 & 12.00 & 33.00 \\
\hline Agrade & 1.30 & 0.135 & 1.06 & 1.90 \\
\hline $\mathbf{2}^{\text {nd }}$ stage & & & & \\
\hline$h$ & 0.36 & 0.17 & 0.13 & 1.00 \\
\hline Edu3 & 0.05 & 0.01 & 0.03 & 0.10 \\
\hline CohortA & 0.07 & 0.00 & 0.06 & 0.07 \\
\hline Dens & 212.92 & 330.17 & 36.00 & 1529.00 \\
\hline Ragr & 0.03 & 0.02 & 0.00 & 0.08 \\
\hline Rune & 0.04 & 0.02 & 0.01 & 0.08 \\
\hline LdistU & 2.83 & 0.78 & 0.00 & 3.87 \\
\hline$Q$ & -1.19 & 13.55 & -30.52 & 32.60 \\
\hline
\end{tabular}

$1^{\text {st }}$ STAGE: Estimating district level public schools' quality

\begin{tabular}{|l|l|}
\hline Agrade & $\begin{array}{l}\text { Grade average of applicants to Gymnazia from Primary school. A measure } \\
\text { similar to elem. } 1<=\text { agrade }<5 ; 1 \text { is the best and 5 the worst. }\end{array}$ \\
\hline Pclass & Pupils/class district ratio in Primary school in district \\
\hline Edu23 & Share of population with at least full-secondary education \\
\hline Townpop & Share of population living in towns \\
\hline & \\
\hline
\end{tabular}

$2^{\text {nd }}$ STAGE: Estimates of non-state school entry (probit)

\begin{tabular}{|l|l|}
\hline Dens & District population density \\
\hline CohortA & $\begin{array}{l}\text { Share of age cohorts 12-15 years of age in December 1991 on the total } \\
\text { district population }\end{array}$ \\
\hline Edu3 & Share of university-educated population \\
\hline Rune & Unemployment rate \\
\hline Ldist & $\begin{array}{l}\text { Log(distance) of districts from university centers: Prague, Brno, Ostrava } \\
\text { (representing about 3/4 of total university enrollment). There are several } \\
\text { other university towns, but these are mainly rather specific and small }\end{array}$ \\
\hline$H$ & Index of public schools' concentration \\
\hline Ragr & Share of employment in agriculture \\
\hline$Q$ & Public schools' quality \\
\hline
\end{tabular}


Table 8b

1st stage estimates of school graduates' quality regression

\begin{tabular}{|l|c|c|c|}
\hline & Coef. & Std. Err. & t-stat \\
\hline Edu23 & 299.39 & 56.51 & 5.30 \\
\hline Townpop & -38.65 & 11.52 & -3.36 \\
\hline Pclass & -83.46 & 52.72 & -1.58 \\
\hline Agrade & -39.96 & 13.68 & -2.92 \\
\hline Const & 209.75 & 68.15 & 3.08 \\
\hline Nobs & & $\mathbf{1 8 7 . 0 0}$ & \\
\hline${\text { Adj } \boldsymbol{R}^{2}}^{\mid}$ & $\mathbf{0 . 1 8}$ & \\
\hline
\end{tabular}


Table 8c

Probit Estimates of the Probability of a Non-state Gymnázium in a District by 1995

\begin{tabular}{|l|c|c|c|c|c|c|}
\hline & \multicolumn{3}{|c|}{$(1)$} & \multicolumn{3}{c|}{$(2)$} \\
\hline & $\mathbf{d F} / \mathbf{d x}$ & Std.Err. & $\mathbf{z}$ & $\mathbf{d F} / \mathbf{d x}$ & Std.Err. & $\mathbf{z}$ \\
\hline H & 0.20 & 0.52 & 0.38 & 23.90 & 7.91 & 2.98 \\
\hline Edu3 & 24.64 & 8.31 & 2.94 & 50.26 & 31.09 & 1.63 \\
\hline DohortA & 56.32 & 32.67 & 1.74 & 0.002 & 0.001 & 1.730 \\
\hline Ragr & 0.003 & 0.002 & 1.790 & - & - & - \\
\hline Rune & 3.42 & 5.27 & 0.65 & - & - & - \\
\hline LdistU & 8.46 & 4.64 & 1.80 & 9.31 & 4.34 & 2.11 \\
\hline Q & -0.11 & 0.15 & -0.73 & - & - & - \\
\hline Nobs & -0.01 & 0.01 & -1.94 & -0.01 & 0.01 & -1.79 \\
\hline pseudo $\boldsymbol{R}^{2}$ & & $\mathbf{7 3}$ & & & $\mathbf{7 3 . 0 0}$ & \\
\hline
\end{tabular}


Table 9

Determinants of Vocational School Enrollment, 1996

(standard errors in parentheses)

\begin{tabular}{|r|c|c|c|}
\hline & $\begin{array}{c}\text { Private } \\
\text { Enrollment/ } \\
\text { Public } \\
\text { Enrollment } \\
\text { (Within Cell) }\end{array}$ & $\begin{array}{c}\text { Private } \\
\text { Enrollment } \\
\text { (Within Cell)/ } \\
\text { Total } \\
\text { Enrollment }\end{array}$ & $\begin{array}{c}\text { Increase in } \\
\text { Public } \\
\text { Enrollment } \\
(\mathbf{1 9 9 1 - 1 9 9 6 )}\end{array}$ \\
\hline Increase in Wage Residual & $.193^{* * *}$ & $.042^{* * *}$ & -.121 \\
& $(.067)$ & $(.015)$ & $(.330)$ \\
\hline Unemployment Rate & $.104^{* *}$ & $.015^{*}$ & -.117 \\
& $(.045)$ & $(.009)$ & $(.189)$ \\
\hline Prague & $.358^{* * *}$ & $.055^{* * *}$ & -.489 \\
& $(.105)$ & $(.021)$ & $(.444)$ \\
\hline Finance \& Business & $.618^{* * *}$ & $.202^{* * *}$ & $.759^{* *}$ \\
& $(.050)$ & $(.012)$ & $(.307)$ \\
\hline Constant & $-.212^{* * *}$ & $-.041^{* * *}$ & .198 \\
& $(.065)$ & $(.013)$ & $(.242)$ \\
\hline Estimation Method & Tobit & Tobit & OLS \\
\hline
\end{tabular}

$* * *$ Significant at $1 \%$ level

$* *$ Significant at $5 \%$ level

*Significant at $10 \%$ level 


\section{Table 10}

Changes in Public School Inputs and Quality, 1996-1998

According to Degree of Competition in 1995

\begin{tabular}{|l|c|c|c|}
\hline & $\begin{array}{c}\text { Little or No } \\
\text { Competition }\end{array}$ & $\begin{array}{c}\text { Moderate } \\
\text { Competition }\end{array}$ & $\begin{array}{c}\text { Extensive } \\
\text { Competition }\end{array}$ \\
\hline $\begin{array}{l}\text { Percentage increase in personal } \\
\text { computers per pupil } \\
(1998 \text { mean PC/Pupil ratio) }\end{array}$ & $\begin{array}{c}+533 \% \\
(0.27)\end{array}$ & $\begin{array}{c}+453 \% \\
(0.22)\end{array}$ & $\begin{array}{c}+683 \% \\
(0.28)\end{array}$ \\
\hline $\begin{array}{l}\text { Percentage change in } \\
\text { mean class size } \\
(1998 \text { mean class size) }\end{array}$ & $\begin{array}{c}-1.8 \% \\
(27.63)\end{array}$ & $\begin{array}{c}-3.2 \% \\
(28.72)\end{array}$ & $\begin{array}{c}-3.4 \% \\
(26.56)\end{array}$ \\
\hline $\begin{array}{l}\text { Relative success in obtaining } \\
\text { admission to university } \\
(1=\text { best, } 77=\text { worst })\end{array}$ & +1.43 & -0.55 & -4.47 \\
\hline Number of districts & 51 & 11 & 15 \\
\hline
\end{tabular}


Table A1

Summary statistics

PANEL A: Perception of non-state schools

\begin{tabular}{|c|c|c|c|c|c|c|}
\hline Variable & Nobs & Mean & Std. Dev. & Min & Max & Variable description \\
\hline Statement No.1 & 1360 & 2.859 & 0.855 & 1 & 4 & $*$ \\
\hline Statement No.2 & 1384 & 3.158 & 0.751 & 1 & 4 & * \\
\hline Statement No.3 & 1326 & 2.062 & 0.804 & 1 & 4 & * \\
\hline Statement No.4 & 1335 & 2.615 & 0.983 & 1 & 4 & $*$ \\
\hline TEACHER & 1411 & 0.099 & 0.299 & 0 & 1 & dummy $=1$ if teacher, 0 otherwise \\
\hline TEACH_PR & 1411 & 0.003 & 0.053 & 0 & 1 & dummy $=1$ if teacher in nonstate school, 0 otherwise \\
\hline EXP_BAD & 1411 & 0.077 & 0.266 & 0 & 1 & $\begin{array}{l}\text { dummy }=1 \text { if child in state-school and poor local } \\
\text { school choice }\end{array}$ \\
\hline EXP_GOOD & 1411 & 0.011 & 0.103 & 0 & 1 & $\begin{array}{l}\text { dummy }=1 \text { if child in non-state school and good local } \\
\text { school choice }\end{array}$ \\
\hline INFORMED & 1411 & 0.444 & 0.497 & 0 & 1 & dummy=1 if school age child present \\
\hline EDU & 1401 & 12.493 & 2.555 & 9 & 17 & years of education \\
\hline EDUMAX & 1028 & 13.554 & 2.412 & 9 & 17 & Maximum parental years of education \\
\hline AGE & 1399 & 41.713 & 14.490 & 18.000 & 86.000 & years of age \\
\hline AGE2 & 1399 & 1.950 & 1.330 & 0.324 & 7.396 & age squared $* 1000$ \\
\hline LEARN & 1191 & 8.653 & 0.511 & 5.298 & 11.350 & $\log$ (monthly earnings) \\
\hline GENDER & 1411 & 0.568 & 0.496 & 0 & 1 & dummy $=1$ if women, 0 otherwise \\
\hline
\end{tabular}

PANEL B: School choice model

\begin{tabular}{|l|c|c|c|c|c|l|}
\hline Variable & Obs & Mean & Std. Dev. & Min & Max & \\
\hline NONSTATE & 595 & 0.049 & 0.216 & 0 & 1 & dummy=1 if nonstate, 0 if state \\
\hline TEACHER & 595 & 0.220 & 0.415 & 0 & 1 & dummy=1 if teacher, 0 otherwise \\
\hline TEACH_PR & 595 & 0.007 & 0.082 & 0 & 1 & dummy=1 if teacher in nonstate school, 0 otherwise \\
\hline AGE & 588 & 39.037 & 6.895 & 23 & 63 & years of age \\
\hline AGE2 & 588 & 1.571 & 0.559 & 0.529 & 3.969 & age squared *1000 \\
\hline LEARN & 525 & 8.796 & 0.471 & 5.298 & 11.350 & log(monthly earnings) \\
\hline EDUMAX & 539 & 14.109 & 2.425 & 9 & 17 & Maximum of parental years of education \\
\hline
\end{tabular}

*Statement No.1: "Private schools serve as competitors to public schools, enhancing quality of schooling."

Statement No.2: "Private schools are accessible mainly to the rich"

Statement No.3: "Private schools are mostly of better quality than public ones."

Statement No.4: "Private schools have the right to get the same funding per student as public schools are getting." 
Table A2

Distribution of answers to statements*

\begin{tabular}{|l|c|c|c|c|c|c|c|c|}
\hline & \multicolumn{2}{|l|}{ Statement No.1 } & \multicolumn{2}{|l|}{ Statement No.2 } & \multicolumn{2}{|l|}{ Statement No.3 } & \multicolumn{2}{l|}{ Statement No.4 } \\
\hline & Freq. & Percent & Freq. & Percent & Freq. & Percent & Freq. & Percent \\
\hline Strong disagreement & 87 & 6.4 & 34 & 2.5 & 318 & 24.0 & 197 & 14.8 \\
\hline Weak disagreement & 345 & 25.4 & 196 & 14.2 & 680 & 51.3 & 410 & 30.7 \\
\hline Weak agreement & 601 & 44.2 & 672 & 48.6 & 256 & 19.3 & 438 & 32.8 \\
\hline Strong agreement & 327 & 24.0 & 482 & 34.8 & 72 & 5.4 & 290 & 21.7 \\
\hline \multicolumn{1}{|c|}{ Total } & $\mathbf{1 3 6 0}$ & $\mathbf{1 0 0}$ & $\mathbf{1 3 8 4}$ & $\mathbf{1 0 0}$ & $\mathbf{1 3 2 6}$ & $\mathbf{1 0 0}$ & $\mathbf{1 3 3 5}$ & $\mathbf{1 0 0}$ \\
\hline
\end{tabular}

*Statement No.1: "Private schools serve as competitors to public schools, enhancing quality of schooling."

Statement No.2: "Private schools are accessible mainly to the rich"

Statement No.3: "Private schools are mostly of better quality than public ones."

Statement No.4: "Private schools have the right to get the same funding per student as public schools are getting." 
Table A3

Coefficients of ordered logit regression models of perception of the role of non-state schools

\begin{tabular}{|c|c|c|c|c|c|c|c|}
\hline & \multicolumn{7}{|c|}{ Statement No.* } \\
\hline & 1 & 1 & 1 & 2 & 4 & 3 & Definition of variables \\
\hline & (1) & (2) & (3) & (4) & (5) & (6) & \\
\hline TEACHER & $(0.041)$ & $(0.066)$ & $(0.437)$ & $(0.455)$ & $(0.054)$ & $(0.000)$ & \\
\hline TEACH_PR & 1.028 & 1.059 & n.a. & -2.214 & 2.577 & 1.450 & dummy $=1$ if teacher in nonstate school, 0 otherwise \\
\hline \multirow[t]{2}{*}{ EXP_BAD } & -0.374 & -0.544 & -0.082 & 0.124 & 0.132 & -0.033 & $\begin{array}{l}\text { dummy }=1 \text { if child in state school and poor local school } \\
\text { choice }\end{array}$ \\
\hline & $(0.064)$ & $(0.033)$ & $(0.805)$ & $(0.557)$ & $(0.526)$ & $(0.874)$ & \\
\hline \multirow[t]{2}{*}{ EXP_GOOD } & 1.311 & 1.218 & 1.801 & -0.097 & 2.527 & 1.357 & $\begin{array}{l}\text { dummy }=1 \text { if child in non-state school and good local } \\
\text { school choice }\end{array}$ \\
\hline & $(0.011)$ & $(0.034)$ & $(0.135)$ & $(0.886)$ & $(0.002)$ & $(0.005)$ & \\
\hline EDU & $(0.731)$ & $(0.810)$ & $(0.714)$ & $(0.051)$ & $(0.437)$ & $(0.000)$ & \\
\hline \multirow[t]{2}{*}{ AGE } & -0.046 & -0.058 & -0.029 & 0.048 & -0.006 & -0.005 & years of age \\
\hline & $(0.034)$ & $(0.043)$ & $(0.383)$ & $(0.087)$ & $(0.826)$ & $(0.812)$ & \\
\hline \multirow[t]{2}{*}{ AGE2 } & 0.470 & 0.569 & 0.324 & -0.328 & 0.095 & 0.019 & age squared $* 1000$ \\
\hline & $(0.050)$ & $(0.076)$ & $(0.372)$ & $(0.285)$ & $(0.736)$ & $(0.941)$ & \\
\hline \multirow[t]{2}{*}{ GENDER } & -0.202 & - & - & -1.570 & 2.782 & -0.028 & dummy=1 if women, 0 if men \\
\hline & $(0.049)$ & - & - & $(0.439)$ & $(0.153)$ & $(0.796)$ & \\
\hline \multirow[t]{2}{*}{ LEARN_M } & - & - & - & -0.185 & 0.106 & - & $\log$ (monthly earnings) of men \\
\hline & - & - & - & $(0.346)$ & $(0.574)$ & - & \\
\hline
\end{tabular}

p-values in parenthesis

*Statement No.1: "Private schools serve as competitors to public schools, enhancing quality of schooling."

Statement No.2: "Private schools are accessible mainly to the rich"

Statement No.3: "Private schools are mostly of better quality than public ones."

Statement No.4: "Private schools have the right to get the same funding per student as public schools are getting."

Dichotomous (4) answers: ranging from strong agreement to strong disagreement 
Table A4

Probit model of nonstate-school choice

\begin{tabular}{|l|c|c|l|}
\hline & $\mathbf{d F} / \mathbf{d x}$ & $\mathbf{d F} / \mathbf{d x}$ & \multicolumn{1}{|c|}{ Definition of variables } \\
\hline & $(\boldsymbol{p}$-value $)$ & $(\boldsymbol{p}$-value $)$ & Dependent variable: Child in nonstate/state school 1/0 \\
\hline & $(\mathbf{1})$ & $(\mathbf{2})$ & \\
\hline TEACHER & -0.027 & -0.039 & Dummy=1 if teacher, 0 otherwise \\
\hline TEACH_PR & $(0.063)$ & $(0.119)$ & \\
\hline AGE & 0.225 & n.a. & Dummy=1 if teacher in nonstate school, 0 otherwise \\
\hline & $(0.080)$ & $n . a$. & \\
\hline AGE2*1000 & -0.014 & -0.020 & Years of age \\
\hline & $(0.069)$ & $(0.193)$ & \\
\hline LEARN & 0.164 & 0.238 & age squared $* 1000$ \\
\hline & $(0.071)$ & $(0.187)$ & \\
\hline EDUMAX & 0.030 & 0.052 & log(monthly earnings) \\
\hline & $(0.024)$ & $(0.020)$ & \\
\hline obs. $\boldsymbol{P}$ & 0.009 & 0.011 & Maximum parental years of education \\
\hline pred. $\boldsymbol{P}$ & $(0.009)$ & $(0.040)$ & \\
\hline Pseudo $\boldsymbol{R} 2$ & $\mathbf{0 . 0 3 8}$ & $\mathbf{0 . 0 5 4}$ & \\
\hline Nobs & $\mathbf{0 . 0 2 4}$ & $\mathbf{0 . 0 3 3}$ & \\
\hline
\end{tabular}

$p$-values in parentheses, $p>|z|$ are the test of the underlying coefficient being 0 ;

$\mathrm{dF} / \mathrm{dx}$ is for discrete change of dummy variable from 0 to 1 


\section{Technical Appendix}

\section{Simple model of non-state school entry}

Non-state schools enter if there is sufficient excess demand $D-S$

$$
y^{*} \equiv D-S=f(Z)+u
$$

we observe entry/no entry

$$
\begin{aligned}
& y=1 \text { if } y^{*}>\bar{y} \\
& y=0 \text { otherwise }
\end{aligned}
$$

Considering simple linear specification and probit model

$$
\begin{array}{ll}
y_{d}{ }^{*}=Z_{d}^{D} \gamma+Q_{d} \delta+u_{d} \\
\mathrm{Z} & \text { excess demand factors } \\
\mathrm{Q} & \text { public school quality } \\
\mathrm{s,d} & \text { school, district subscripts }
\end{array}
$$

Modeling public school quality $Q_{s d}$

$q_{s d}=g\left(X_{s d}\right)+Q_{s d}+\varepsilon_{s d}$

$\mathrm{q}_{\mathrm{sd}} \quad$ quality of school graduates

$\mathrm{Q}_{\text {sd }} \quad$ school quality (value added)

$\mathrm{g}($.$) \quad quality of enrolled students$

$\mathrm{X}_{\mathrm{sd}} \quad$ characteristics of enrolled students and district conditions

Assuming simple linear specification

$$
q_{s d}=X_{s d}^{1} \alpha+X_{d}^{2} \beta+Q_{s d}+\varepsilon_{s d}
$$

Predicted public school quality

$$
\hat{Q}_{s d}=q_{s d}-X_{s d}^{1} \hat{\alpha}-X_{d}^{2} \hat{\beta}
$$

Predicted public schooling quality at district

$$
\hat{Q}_{d}=\sum_{s} \hat{Q}_{s d} \sigma_{s d}
$$

where $\sigma_{s d}$ represents share of school $s$ on total enrolment in district public schools. 
Figure 1A:

Fraction of Cohort in Various Types of Secondary Schools

(Czech Republic)

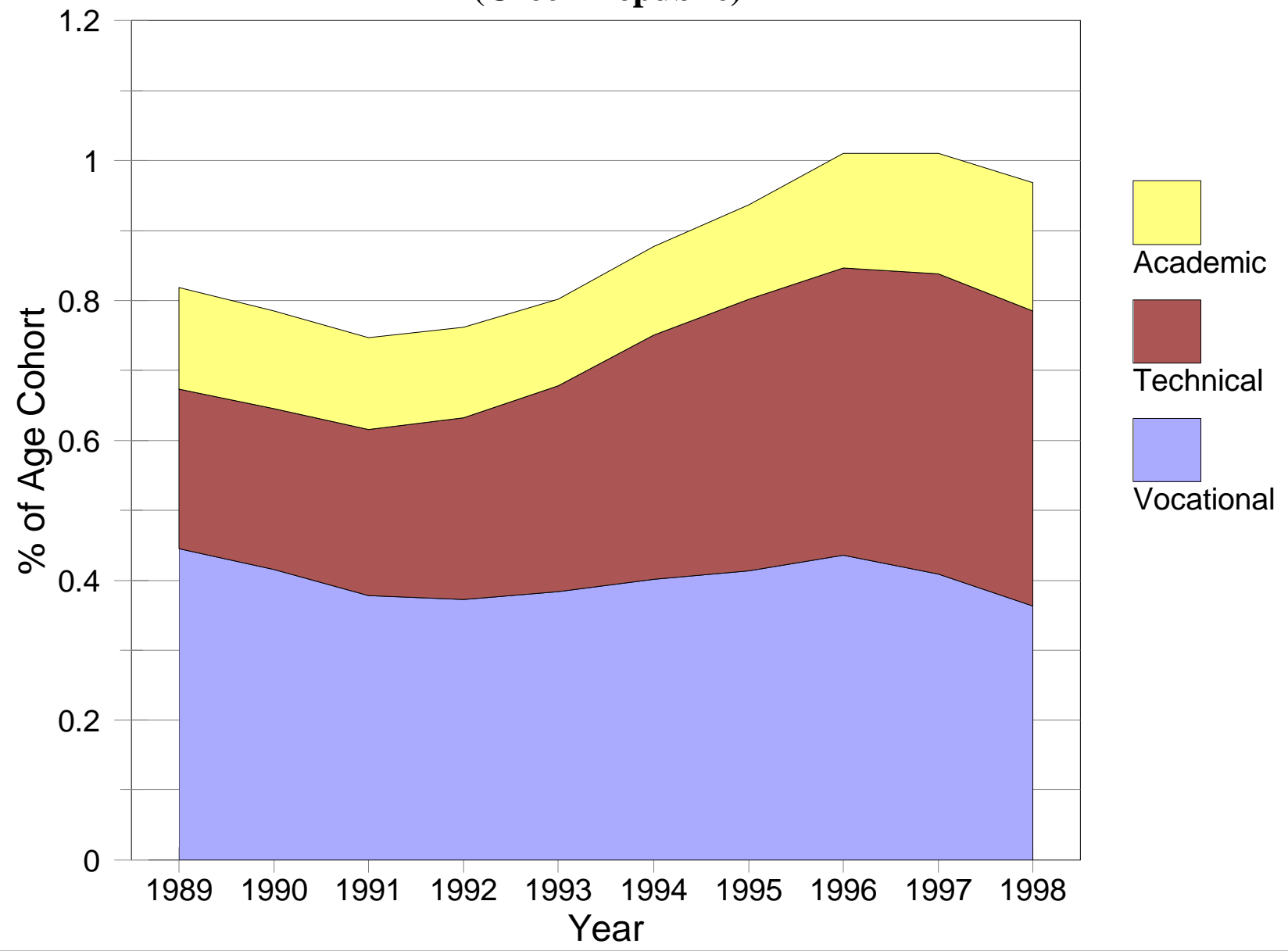




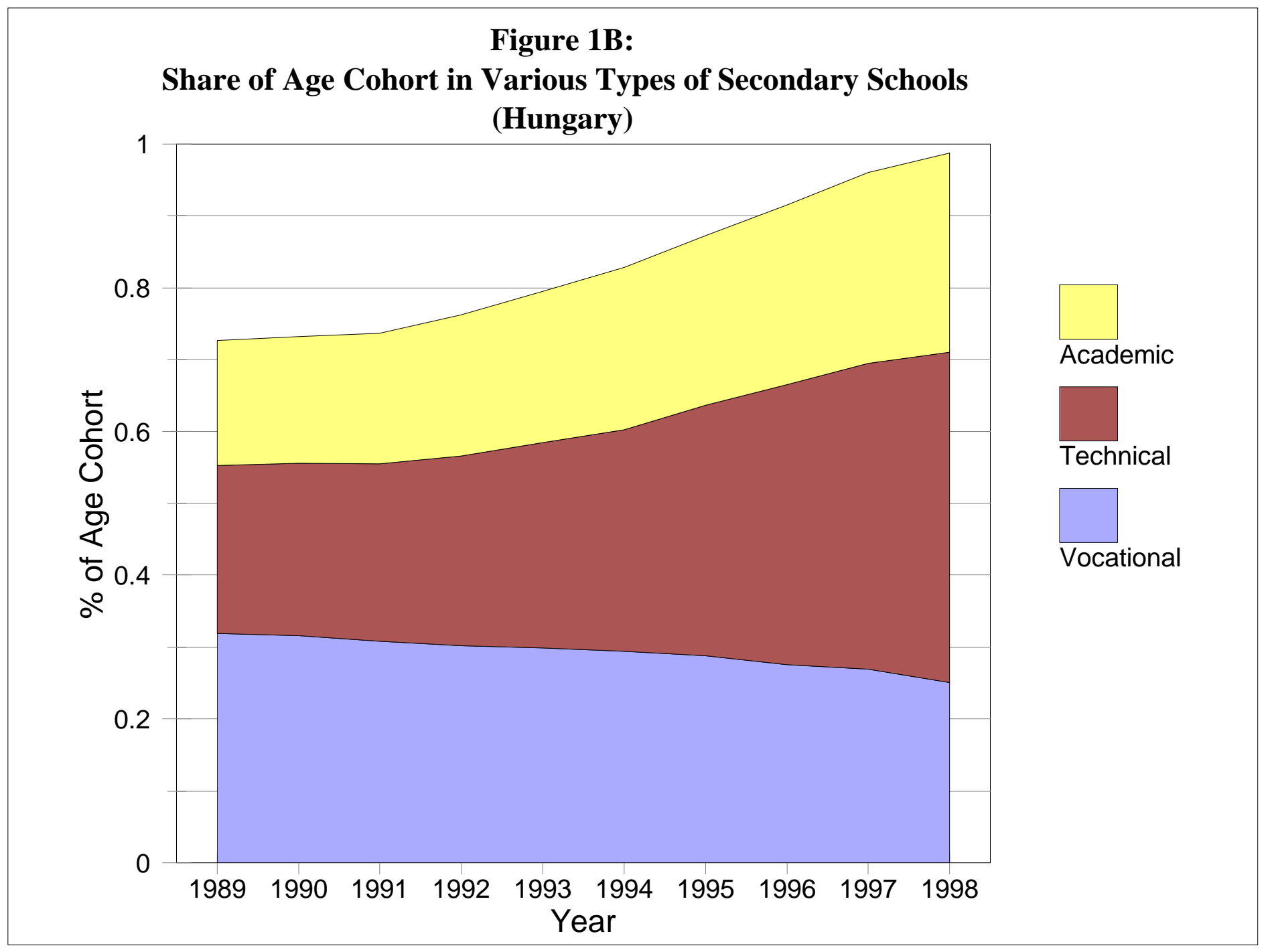


Figure 2A:

Applicants and Admissions to University

(Czech Republic)

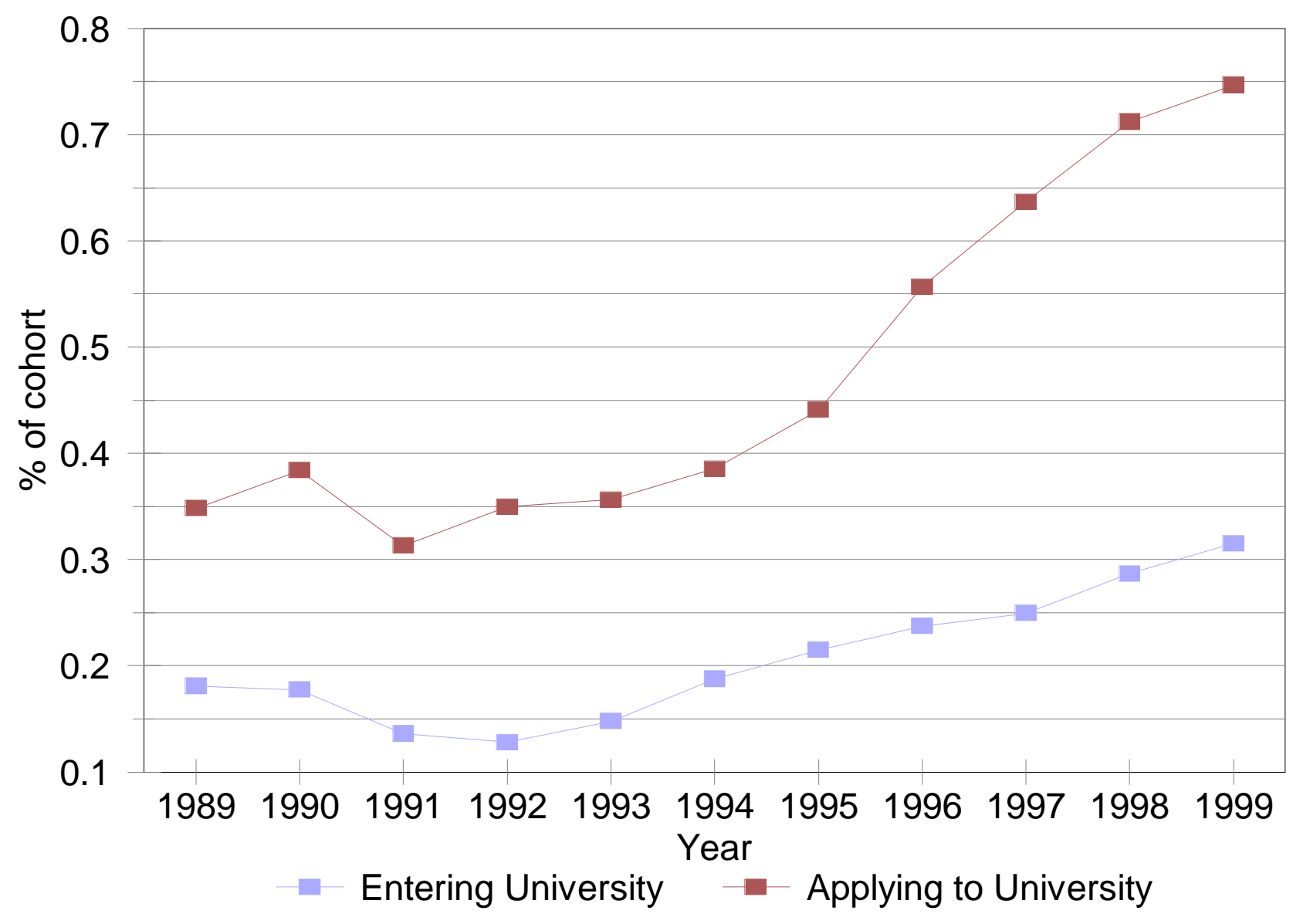




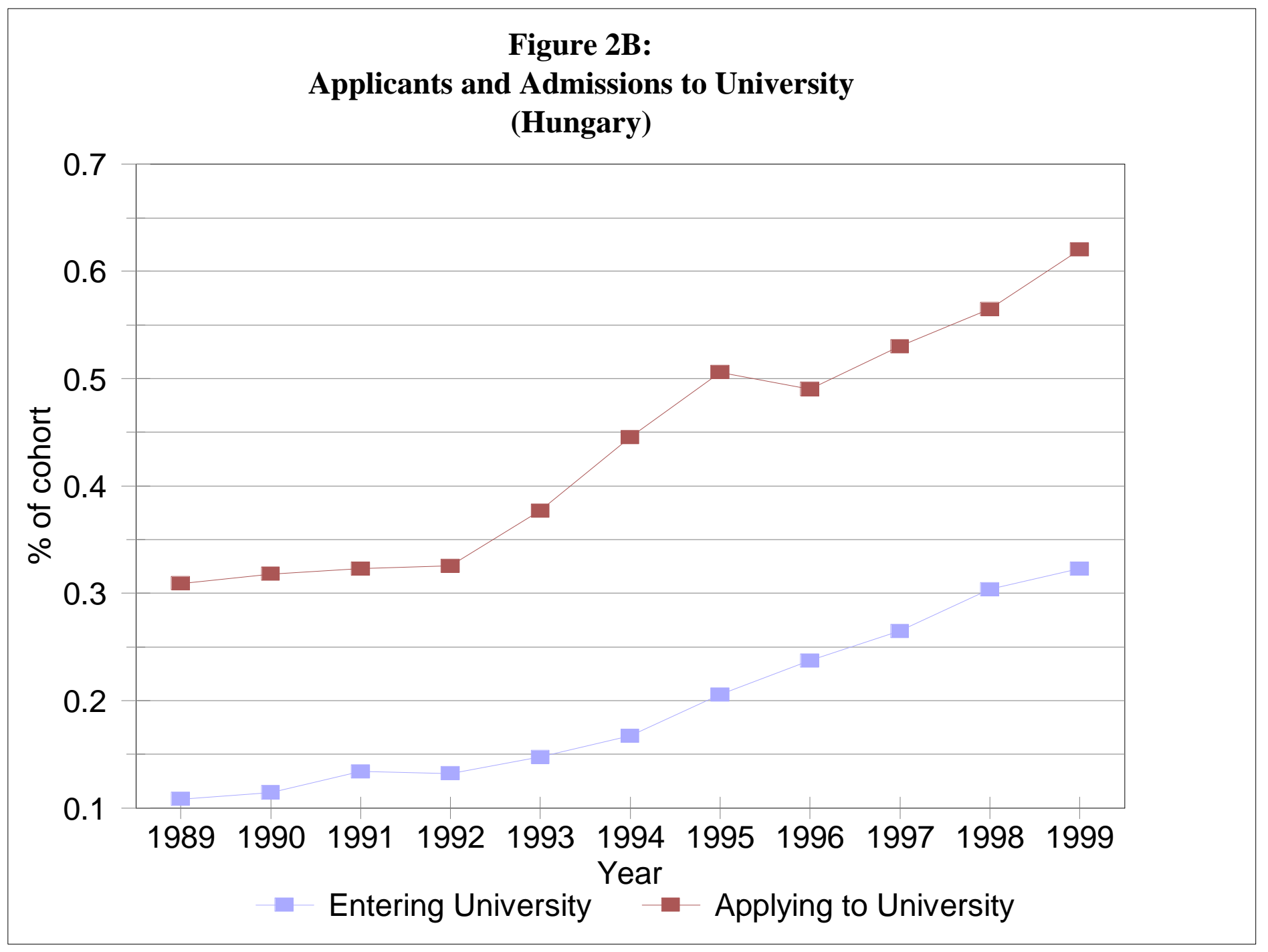


Figure 3A:

Fraction of Cohort Enrolled in Secondary School

(Czech Republic)

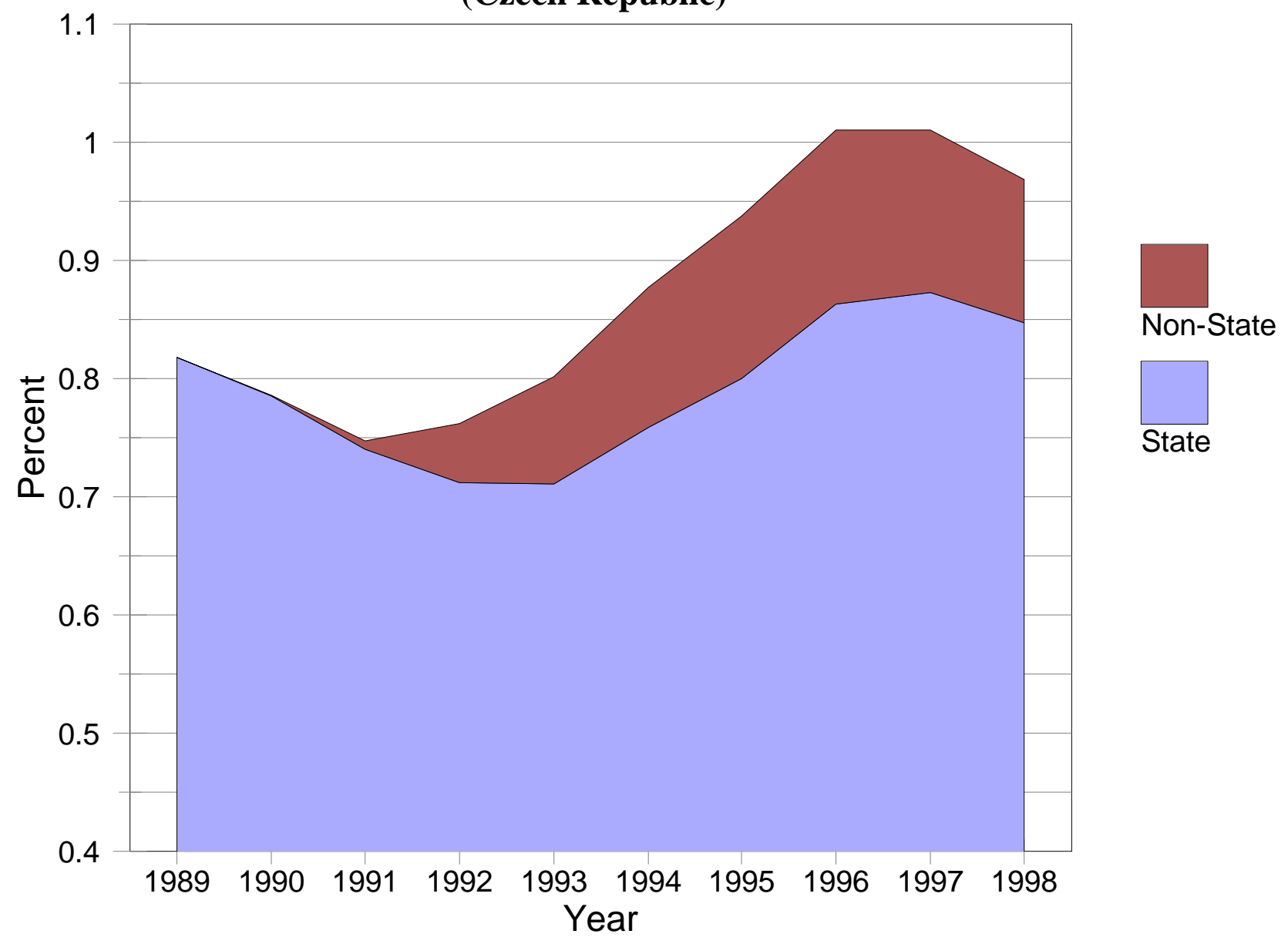


Figure 3B:

Fraction of Cohort Enrolled in Secondary School (Hungary)

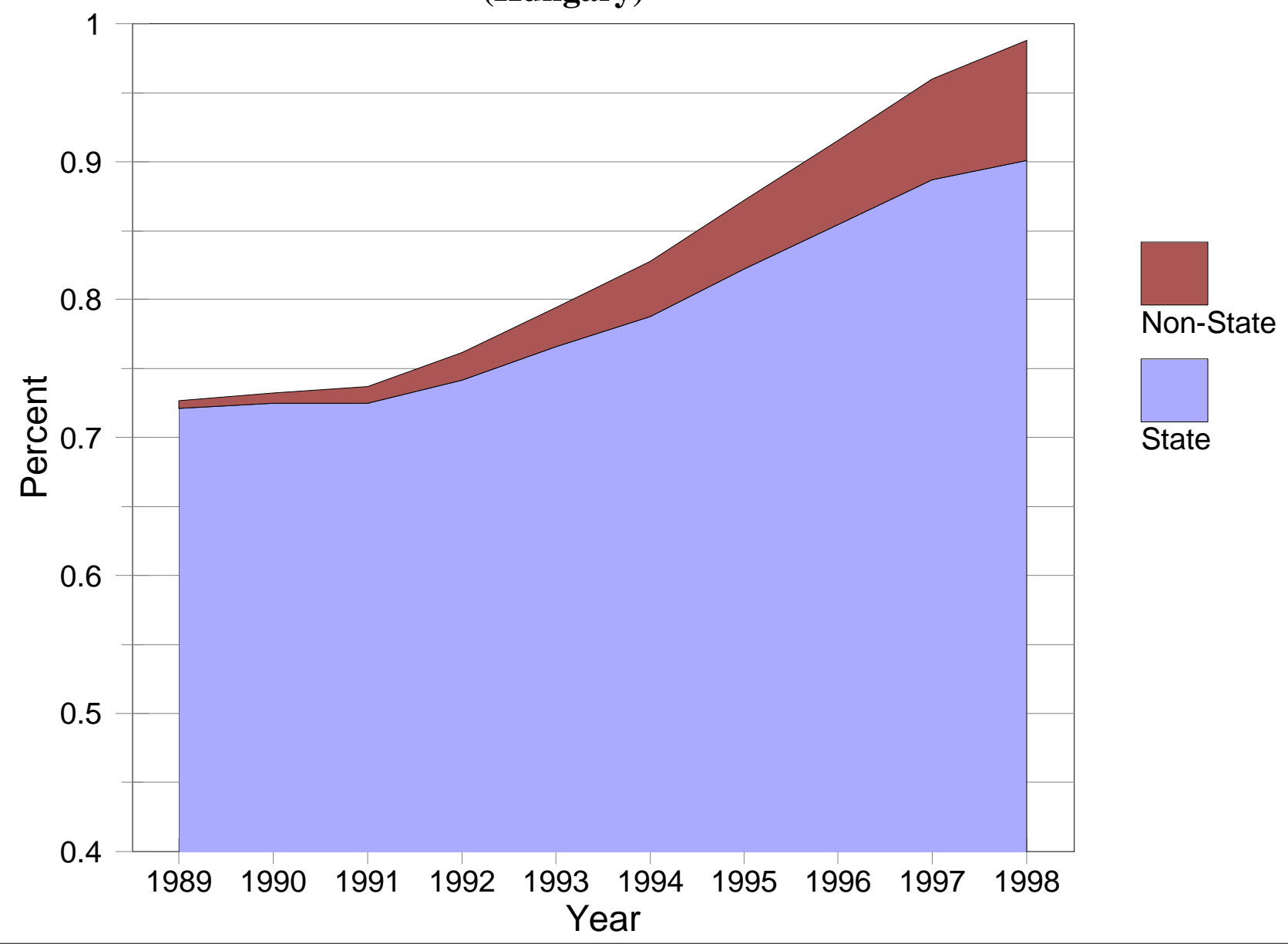


Figure 4A:

Fraction of Cohort in State and Nonstate Academic High Schools

(Czech Republic)

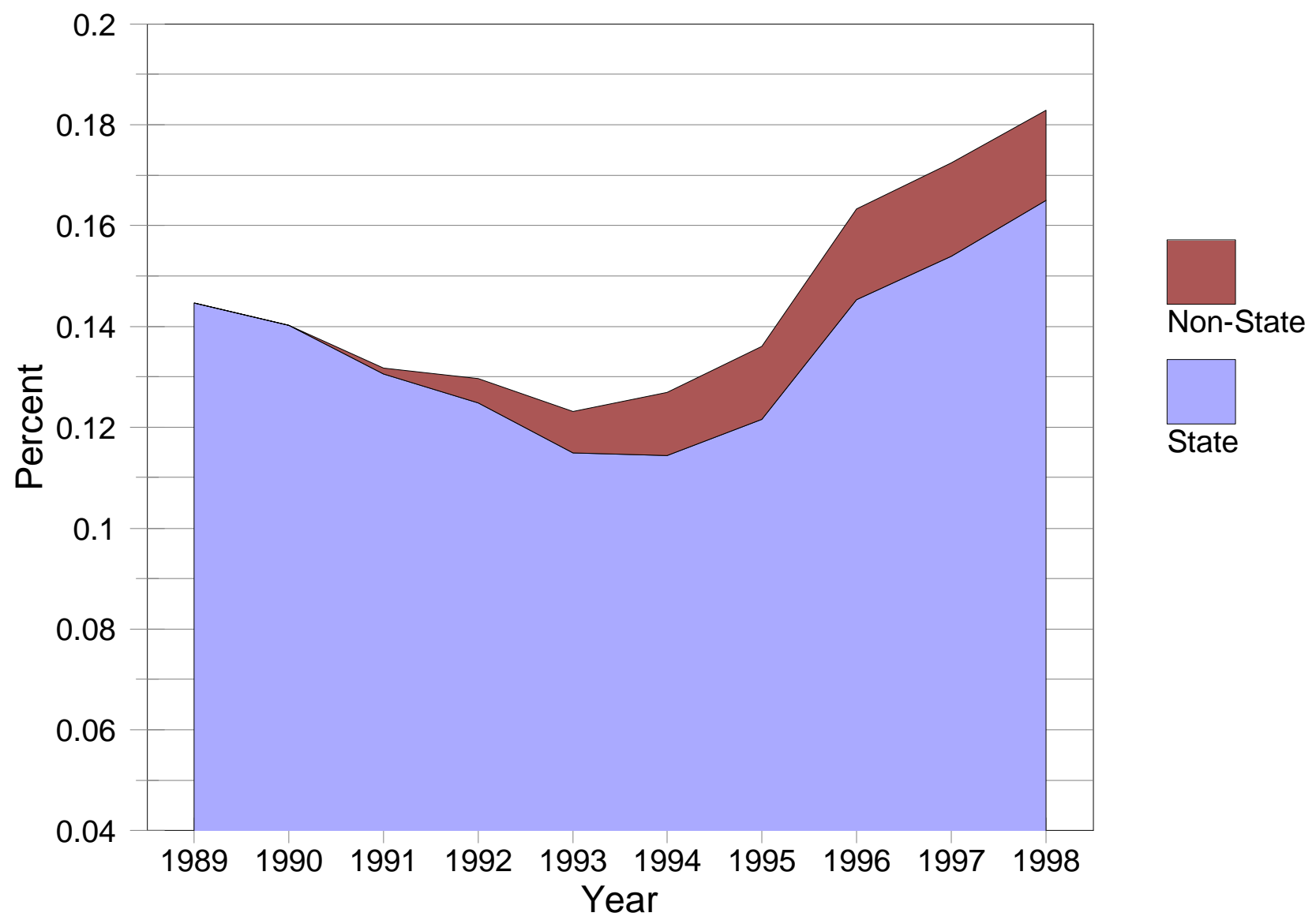


Figure 4B:

Fraction of Cohort in State and Nonstate Academic High Schools (Hungary)

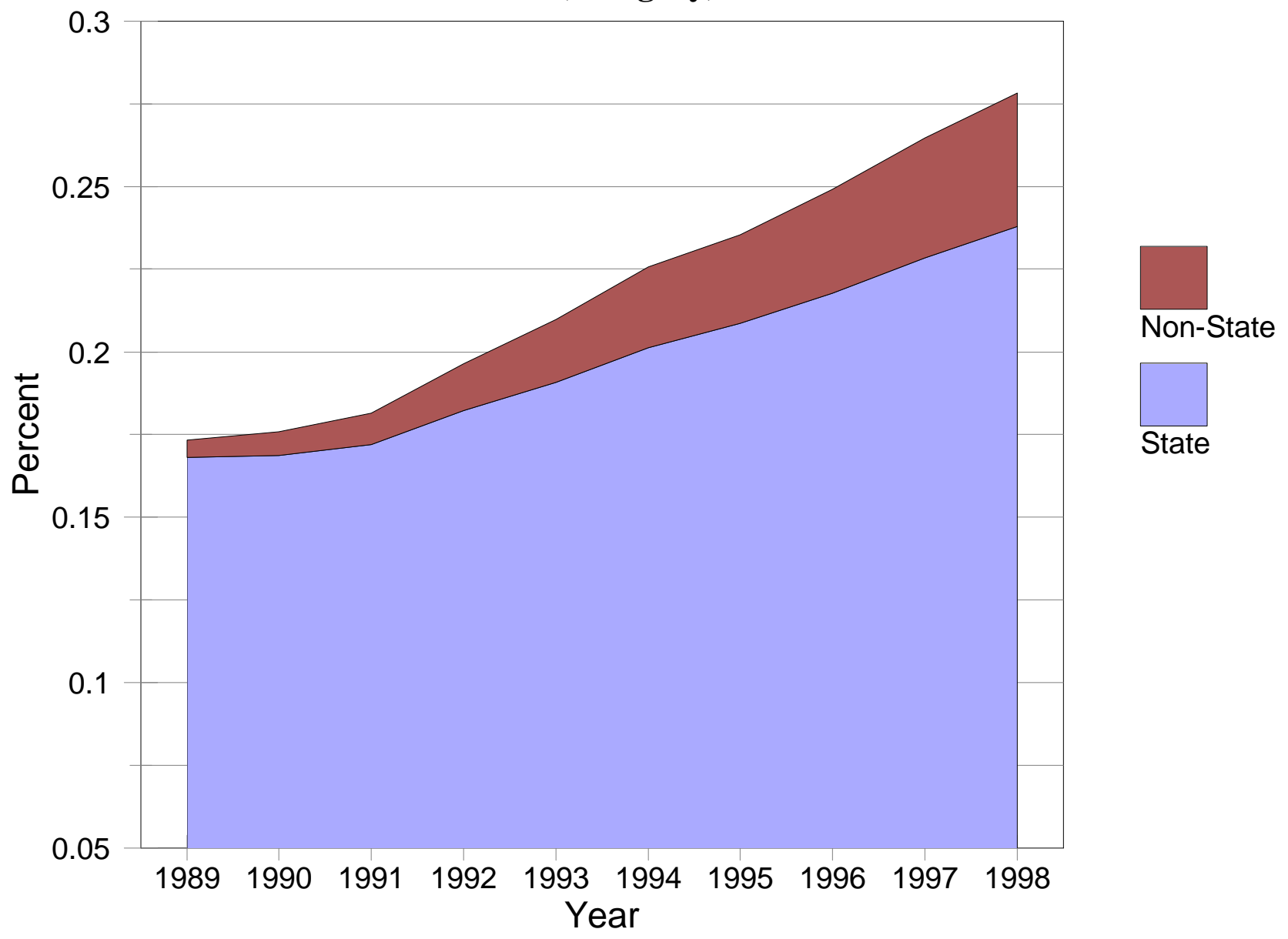


Figure 5A:

Fraction of Cohort in State and Nonstate High Schools

(Czech Republic)

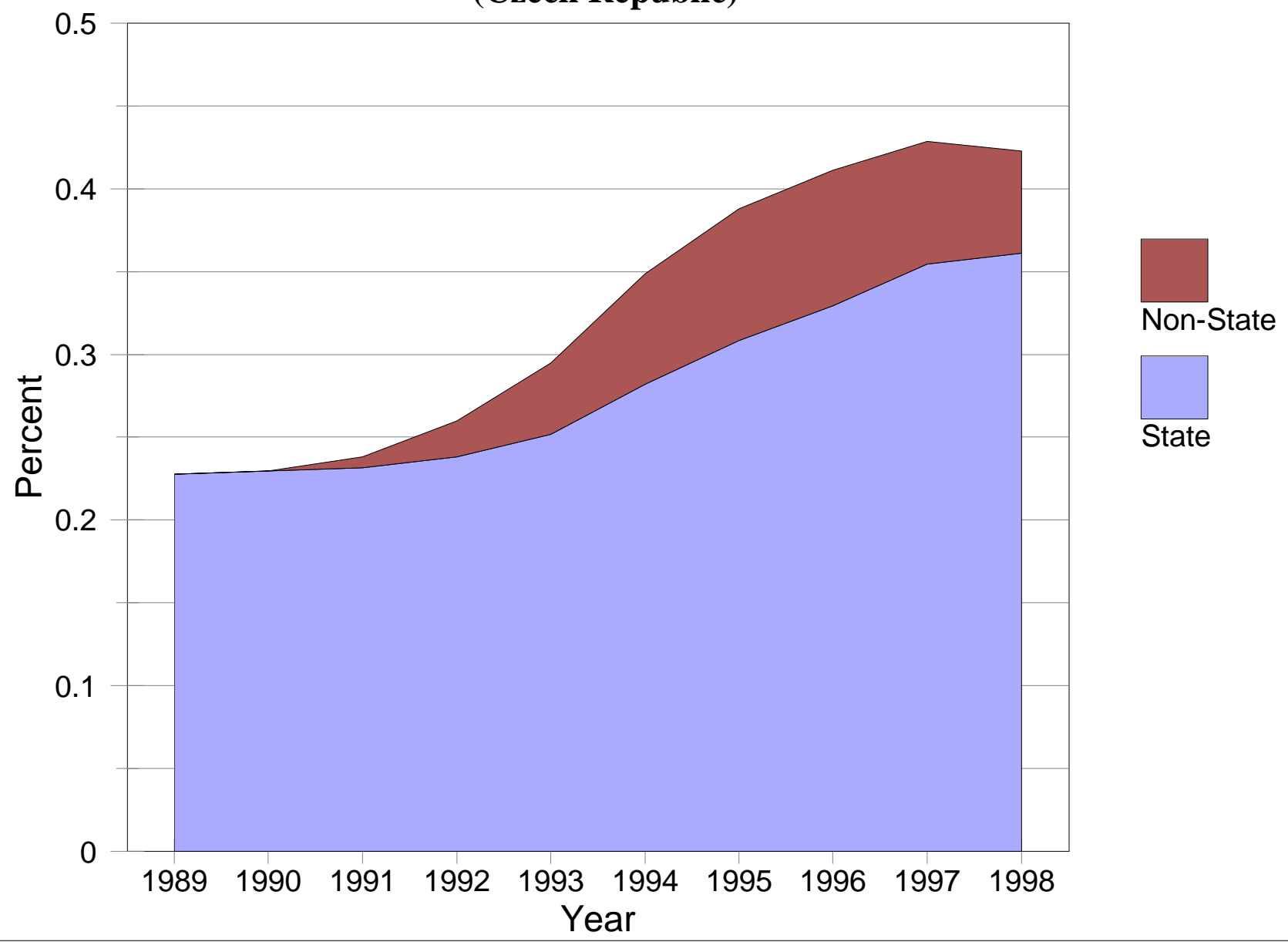




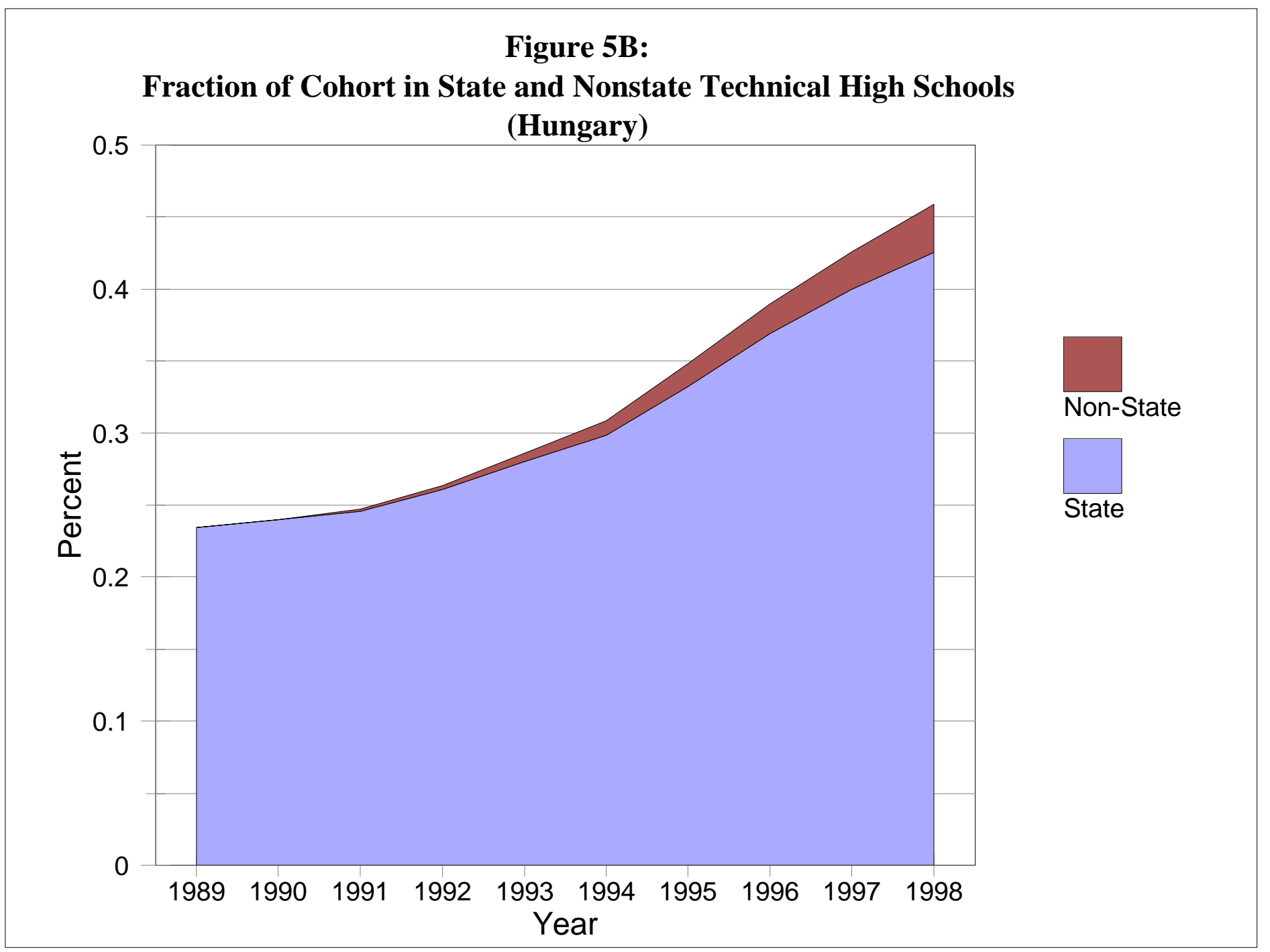


Figure 6A:

Fraction of Cohort in State and Nonstate Vocational Schools

(Czech Republic)

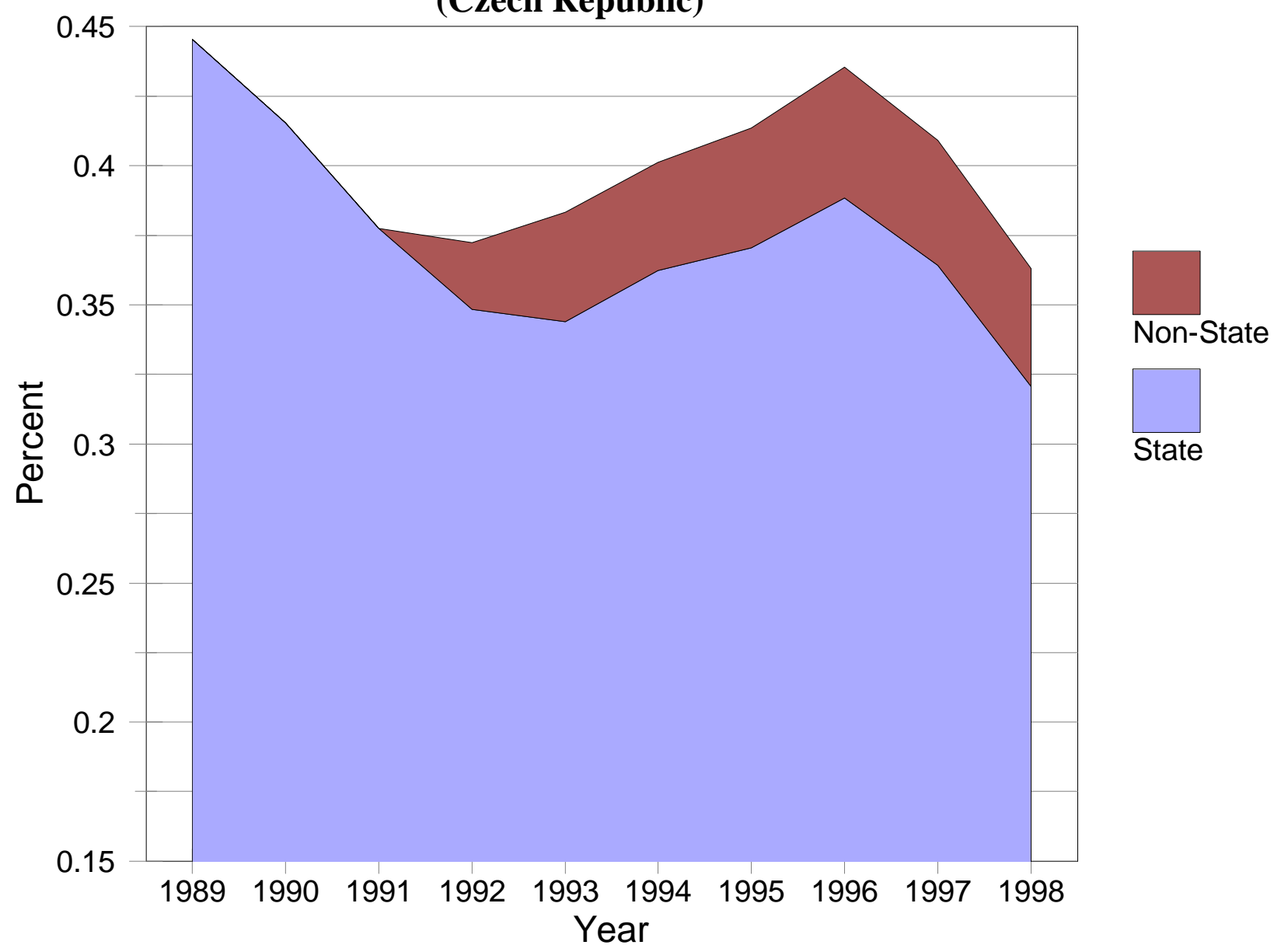




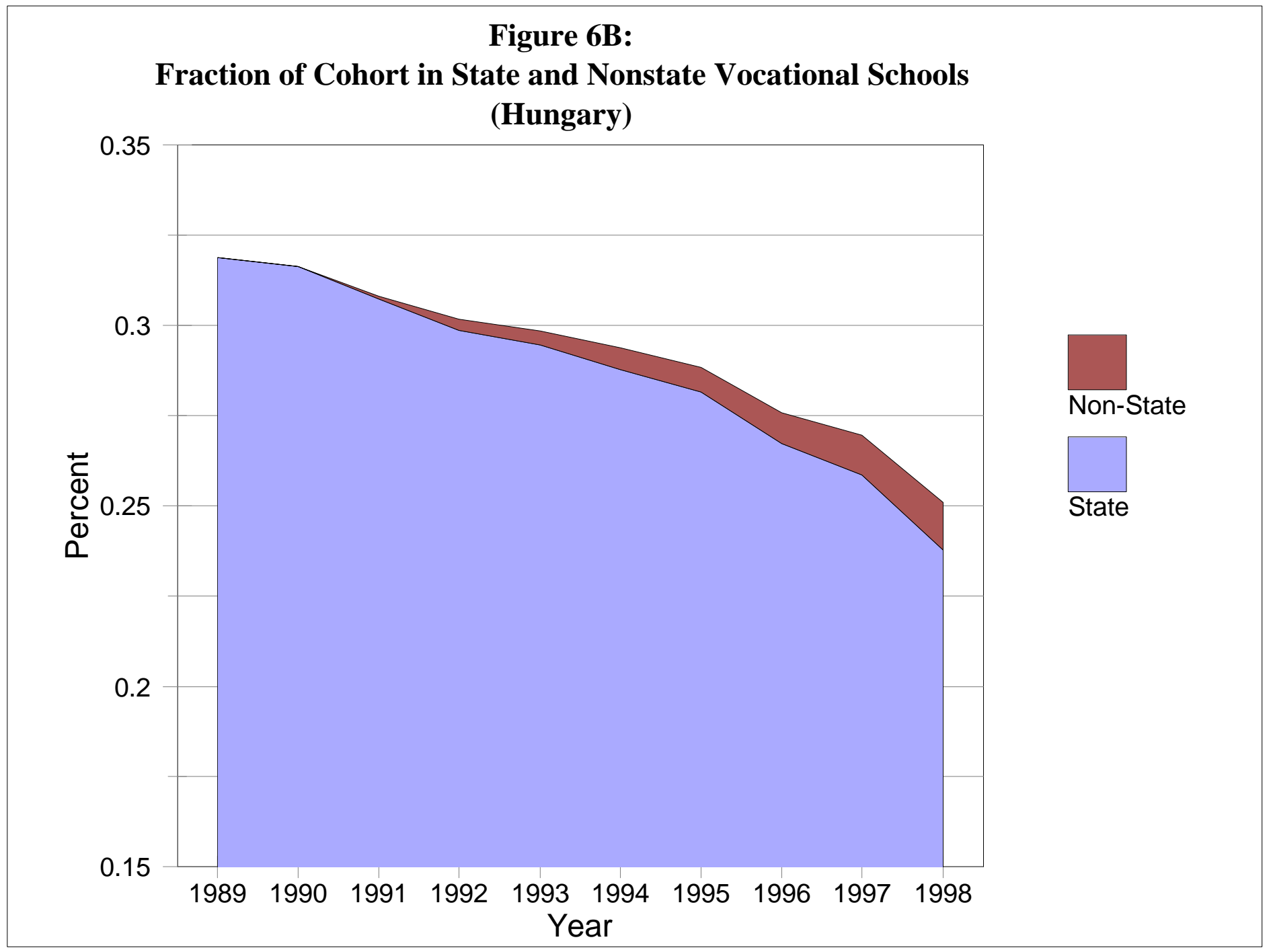




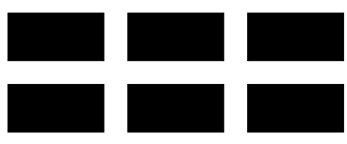

THE WiLliam DAVIDSON INSTITUTE

AT THE UNIVERSITY OF MICHIGAN BUSINESSSCHOOL

\section{DAVIDSON INSTITUTE WORKING PAPER SERIES - Most Recent Papers}

The entire Working Paper Series is available at: www.wdi.bus.umich.edu

CURRENT AS OF $1 / 31 / 01$

\begin{tabular}{|c|c|c|}
\hline Publication & Authors & Date \\
\hline $\begin{array}{l}\text { No. } 360 \text { Responses of Private and Public Schools to Voucher Funding: } \\
\text { The Czech and Hungarian Experience }\end{array}$ & $\begin{array}{l}\text { Randall K. Filer and Daniel } \\
\text { Münich }\end{array}$ & Oct. 2000 \\
\hline $\begin{array}{l}\text { No. } 359 \text { Labor Market Uncertainty and Private Sector Labor Supply in } \\
\text { Russia }\end{array}$ & Steven Stillman & Sept. 2000 \\
\hline $\begin{array}{l}\text { No. } 358 \text { Russian Roulette-Expenditure Inequality and Instability in } \\
\text { Russia, 1994-1998 }\end{array}$ & Branko Jovanovic & Sept. 2000 \\
\hline No. 357 Dealing with the Bad Loans of the Chinese Banks & John P. Bonin and Yiping Huang & Jan. 2001 \\
\hline No. 356 Retail Banking in Hungary: A Foreign Affair? & John P. Bonin and István Ábel & Dec. 2000 \\
\hline $\begin{array}{l}\text { No. } 355 \text { Optimal Speed of Transition: Micro Evidence from the Czech } \\
\text { Republic }\end{array}$ & $\begin{array}{l}\text { Stepan Jurajda and Katherine } \\
\text { Terrell }\end{array}$ & Dec. 2000 \\
\hline No. 354 Political Instability and Growth in Dictatorships & $\begin{array}{l}\text { Jody Overland, Kenneth L. } \\
\text { Simons and Michael Spagat }\end{array}$ & Nov. 2000 \\
\hline No. 353 Disintegration and Trade & Jarko Fidrmuc and Jan Fidrmuc & Nov. 2000 \\
\hline $\begin{array}{l}\text { No. } 352 \text { Social Capital and Entrepreneurial Performance in Russia: A } \\
\text { Panel Study }\end{array}$ & Bat Batjargal & Dec. 2000 \\
\hline $\begin{array}{l}\text { No. 351 Entrepreneurial Versatility, Resources and Firm Performance in } \\
\text { Russia: A Panel Study }\end{array}$ & Bat Batjargal & Dec. 2000 \\
\hline $\begin{array}{l}\text { No. } 350 \text { The Dynamics of Entrepreneurial Networks in a Transitional } \\
\text { Economy: The Case of Russia }\end{array}$ & Bat Batjargal & Dec. 2000 \\
\hline $\begin{array}{l}\text { No. } 349 \text { R\&D and Technology Spillovers via FDI: Innovation and } \\
\text { Absorptive Capacity }\end{array}$ & Yuko Kinoshita & Nov. 2000 \\
\hline $\begin{array}{l}\text { No. } 348 \text { Microeconomic aspects of Economic Growth in Eastern } \\
\text { Europe and the Former Soviet Union, } 1950-2000\end{array}$ & Sergei Guriev and Barry W. Ickes & Nov. 2000 \\
\hline $\begin{array}{l}\text { No. } 347 \text { Effective versus Statutory Taxation: Measuring Effective Tax } \\
\text { Administration in Transition Economies }\end{array}$ & $\begin{array}{l}\text { Mark E. Schaffer and Gerard } \\
\text { Turley }\end{array}$ & Nov. 2000 \\
\hline $\begin{array}{l}\text { No. } 346 \text { Objectives and Constraints of Entrepreneurs: Evidence from } \\
\text { Small and Medium Size Enterprises in Russia and Bulgaria }\end{array}$ & $\begin{array}{l}\text { Francesca Pissarides, Miroslav } \\
\text { Singer and Jan Svejnar }\end{array}$ & Oct. 2000 \\
\hline No. 345 Corruption and Anticorruption in the Czech Republic & $\begin{array}{l}\text { Lubomír Lízal and Evžen } \\
\text { Kočenda }\end{array}$ & Oct. 2000 \\
\hline No. 344 The Effects of Direct Foreign Investment on Domestic Firms & Jozef Konings & Oct. 2000 \\
\hline No. 343 On the Identification of Relative Wage Rigidity Dynamics & Patrick A. Puhani & Oct. 2000 \\
\hline $\begin{array}{l}\text { No. } 342 \text { The Determinants of Foreign Direct Investment in Transition } \\
\text { Economies }\end{array}$ & Alan A. Bevan and Saul Estrin & Oct. 2000 \\
\hline No. 341 The Global Spread of Stock Exchanges, 1980-1998 & Klaus Weber and Gerald F. Davis & Nov. 2000 \\
\hline $\begin{array}{l}\text { No. } 340 \text { The Costs and Benefits of Euro-isation in Central-Eastern } \\
\text { Europe Before or Instead of EMU Membership }\end{array}$ & D. Mario Nuti & Oct. 2000 \\
\hline No. 339 Debt Overhang and Barter in Russia & $\begin{array}{l}\text { Sergei Guriev, Igor Makarov and } \\
\text { Mathilde Maurel }\end{array}$ & Sept. 2000 \\
\hline $\begin{array}{l}\text { No. } 338 \text { Firm Performance and the Political Economy of Corporate } \\
\text { Governance: Survey Evidence for Bulgaria, Hungary, Slovakia and } \\
\text { Slovenia }\end{array}$ & $\begin{array}{l}\text { Patrick Paul Walsh and Ciara } \\
\text { Whela }\end{array}$ & July 2000 \\
\hline No. 337 Investment and Instability & $\begin{array}{l}\text { Nauro F. Campos and Jeffrey B. } \\
\text { Nugent }\end{array}$ & May 2000 \\
\hline $\begin{array}{l}\text { No. } 336 \text { The Evolution of the Insurance Sector in Central and } \\
\text { Eastern Europe and the former Soviet Union }\end{array}$ & Robert B.K. Pye & Aug. 2000 \\
\hline $\begin{array}{l}\text { No. } 335 \text { Institutional Technology and the Chains of Trust: Capital } \\
\text { Markets and Privatization in Russia and the Czech Republic }\end{array}$ & Bruce Kogut and Andrew Spicer & Aug. 2000 \\
\hline
\end{tabular}


The entire Working Paper Series is available at: www.wdi.bus.umich.edu

\begin{tabular}{|c|c|c|}
\hline No. 334 The Evolution of Market Integration in Russia & $\begin{array}{l}\text { Daniel Berkowitz and David N. } \\
\text { DeJong }\end{array}$ & Aug. 2000 \\
\hline No. 333 Efficiency and Market Share in Hungarian Corporate Sector & László Halpern and Gábor Körösi & July 2000 \\
\hline No. 332 Search-Money-and-Barter Models of Financial Stabilization & $\begin{array}{l}\text { S.I. Boyarchenko and S.Z. } \\
\text { Levendorskii }\end{array}$ & July 2000 \\
\hline $\begin{array}{l}\text { No. } 331 \text { Worker Training in a Restructuring Economy: Evidence from } \\
\text { the Russian Transition }\end{array}$ & $\begin{array}{l}\text { Mark C. Berger, John S. Earle } \\
\text { and Klara Z. Sabirianova }\end{array}$ & Aug. 2000 \\
\hline $\begin{array}{l}\text { No. } 330 \text { Economic Development in Palanpur 1957-1993: A Sort of } \\
\text { Growth }\end{array}$ & Peter Lanjouw & Aug. 2000 \\
\hline $\begin{array}{l}\text { No. } 329 \text { Trust, Organizational Controls, Knowledge Acquisition from } \\
\text { the Foreign Parents, and Performance in Vietnamese International Joint } \\
\text { Ventures }\end{array}$ & $\begin{array}{l}\text { Marjorie A. Lyles, Le Dang } \\
\text { Doanh, and Jeffrey Q. Barden }\end{array}$ & June 2000 \\
\hline $\begin{array}{l}\text { No. } 328 \text { Comparative Advertising in the Global Marketplace: The } \\
\text { Effects of Cultural Orientation on Communication }\end{array}$ & $\begin{array}{l}\text { Zeynep Gürhan-Canli and } \\
\text { Durairaj Maheswaran }\end{array}$ & Aug. 2000 \\
\hline No. 327 Post Privatization Enterprise Restructuring & Morris Bornstein & July 2000 \\
\hline No. 326 Who is Afraid of Political Instability? & $\begin{array}{l}\text { Nauro F. Campos and Jeffrey B. } \\
\text { Nugent }\end{array}$ & July 2000 \\
\hline No. 325 Business Groups, the Financial Market and Modernization & Raja Kali & June 2000 \\
\hline $\begin{array}{l}\text { No. } 324 \text { Restructuring with What Success? A Case Study of Russian } \\
\text { Firms }\end{array}$ & Susan Linz & July 2000 \\
\hline $\begin{array}{l}\text { No. } 323 \text { Priorities and Sequencing in Privatization: Theory and } \\
\text { Evidence from the Czech Republic }\end{array}$ & $\begin{array}{l}\text { Nandini Gupta, John C. Ham and } \\
\text { Jan Svejnar }\end{array}$ & May 2000 \\
\hline $\begin{array}{l}\text { No. } 322 \text { Liquidity, Volatility, and Equity Trading Costs Across } \\
\text { Countries and Over Time }\end{array}$ & $\begin{array}{l}\text { Ian Domowitz, Jack Glen and } \\
\text { Ananth Madhavan }\end{array}$ & Mar. 2000 \\
\hline $\begin{array}{l}\text { No. } 321 \text { Equilibrium Wage Arrears: A Theoretical and Empirical } \\
\text { Analysis of Institutional Lock-In }\end{array}$ & $\begin{array}{l}\text { John S. Earle and Klara Z. } \\
\text { Sabirianova }\end{array}$ & Oct. 2000 \\
\hline No. 320 Rethinking Marketing Programs for Emerging Markets & $\begin{array}{l}\text { Niraj Dawar and Amitava } \\
\text { Chattopadhyay }\end{array}$ & June 2000 \\
\hline tions & $\begin{array}{l}\text { Daniel Daianu and Radu } \\
\text { Vranceanu }\end{array}$ & June 2000 \\
\hline $\begin{array}{l}\text { No. } 318 \text { Some Econometric Evidence on the Effectiveness of Active } \\
\text { Labour Market Programmes in East Germany }\end{array}$ & $\begin{array}{l}\text { Martin Eichler and Michael } \\
\text { Lechner }\end{array}$ & June 2000 \\
\hline No. 317 A Model of Russ & R.E Ericson and B.W Ickes & May 2000 \\
\hline $\begin{array}{l}\text { No. } 316 \text { Financial Institutions, Financial Contagion, and Financial } \\
\text { Crises }\end{array}$ & $\begin{array}{l}\text { Haizhou Huang and Chenggang } \\
\mathrm{Xu}\end{array}$ & Mar. 2000 \\
\hline $\begin{array}{l}\text { No. } 315 \text { Privatization versus Regulation in Developing Economies: The } \\
\text { Case of West African Banks }\end{array}$ & $\begin{array}{l}\text { Jean Paul Azam, Bruno Biais, and } \\
\text { Magueye Dia }\end{array}$ & Feb. 2000 \\
\hline $\begin{array}{l}\text { No. } 314 \text { Is Life More Risky in the Open? Household Risk-Coping and } \\
\text { the Opening of China's Labor Markets }\end{array}$ & John Giles & Apr. 2000 \\
\hline $\begin{array}{l}\text { No. } 313 \text { Networks, Migration and Investment: Insiders and Outsiders in } \\
\text { Tirupur's Production Cluster }\end{array}$ & $\begin{array}{l}\text { Abhijit Banerjee and Kaivan } \\
\text { Munshi }\end{array}$ & Mar. 2000 \\
\hline $\begin{array}{l}\text { No. } 312 \text { Computational Analysis of the Impact on India of the Uruguay } \\
\text { Round and the Forthcoming WTO Trade Negotiations }\end{array}$ & $\begin{array}{l}\text { Rajesh Chadha, Drusilla K. } \\
\text { Brown, Alan V. Deardorff and } \\
\text { Robert M. Stern }\end{array}$ & Mar. 2000 \\
\hline No. 311 Subsidized Jobs for Unemployed Workers in Slovakia & Jan. C. van Ours & May 2000 \\
\hline No. 310 Determinants of Managerial Pay in the Czech Republic & $\begin{array}{l}\text { Tor Eriksson, Jaromir Gottvald } \\
\text { and Pavel Mrazek }\end{array}$ & May 2000 \\
\hline $\begin{array}{l}\text { No. } 309 \text { The Great Human Capital Reallocation: An Empirical Analysis } \\
\text { of Occupational Mobility in Transitional Russia }\end{array}$ & Klara Z. Sabirianova & Oct. 2000 \\
\hline No. 308 Economic Development, Legality, and the Transplant Effect & $\begin{array}{l}\text { Daniel Berkowitz, Katharina } \\
\text { Pistor, and Jean-Francois Richard }\end{array}$ & Feb. 2000 \\
\hline $\begin{array}{l}\text { No. } 307 \text { Community Participation, Teacher Effort, and Educational } \\
\text { Outcome: The Case of El Salvador's EDUCO Program }\end{array}$ & Yasuyuki Sawada & Nov. 1999 \\
\hline No. 306 Gender Wage Gap and Segregation in Late Transition & Stepan Jurajda & May 2000 \\
\hline $\begin{array}{l}\text { No. } 305 \text { The Gender Pay Gap in the Transition from Communism: } \\
\text { Some Empirical Evidence }\end{array}$ & Andrew Newell and Barry Reilly & May 2000 \\
\hline
\end{tabular}




\begin{tabular}{|c|c|c|}
\hline No. 304 Post-Unification Wage Growth in East Germany & Jennifer Hunt & Nov. 1998 \\
\hline $\begin{array}{l}\text { No. } 303 \text { How Does Privatization Affect Workers? The Case of the } \\
\text { Russian Mass Privatization Program }\end{array}$ & Elizabeth Brainerd & May 2000 \\
\hline $\begin{array}{l}\text { No. } 302 \text { Liability for Past Environmental Contamination and } \\
\text { Privatization }\end{array}$ & Dietrich Earnhart & Mar. 2000 \\
\hline No. 301 Varieties, Jobs and EU Enlargement & $\begin{array}{l}\text { Tito Boeri and Joaquim Oliveira } \\
\text { Martins }\end{array}$ & May 2000 \\
\hline No. 300 Employer Size Effects in Russia & Todd Idson & Apr. 2000 \\
\hline $\begin{array}{l}\text { No. } 299 \text { Information Complements, Substitutes, and Strategic Product } \\
\text { Design }\end{array}$ & $\begin{array}{l}\text { Geoffrey G. Parker and Marshall } \\
\text { W. Van Alstyne }\end{array}$ & Mar. 2000 \\
\hline $\begin{array}{l}\text { No. } 298 \text { Markets, Human Capital, and Inequality: Evidence from Rural } \\
\text { China }\end{array}$ & $\begin{array}{l}\text { Dwayne Benjamin, Loren Brandt, } \\
\text { Paul Glewwe, and Li Guo }\end{array}$ & May 2000 \\
\hline No. 297 Corporate Governance in the Asian Financial Crisis & $\begin{array}{l}\text { Simon Johnson, Peter Boone, } \\
\text { Alasdair Breach, and Eric } \\
\text { Friedman }\end{array}$ & Nov. 1999 \\
\hline No. 296 Competition and Firm Performance: Lessons from Russia & J. David Brown and John S. Earle & Mar. 2000 \\
\hline No. 295 Wage Determination in Russia: An Econometric Investigation & $\begin{array}{l}\text { Peter J. Luke and Mark E. } \\
\text { Schaffer }\end{array}$ & Mar. 2000 \\
\hline $\begin{array}{l}\text { No. 294: Can Banks Promote Enterprise Restructuring?: Evidence From } \\
\text { a Polish Bank's Experience }\end{array}$ & John P. Bonin and Bozena Leven & Mar. 2000 \\
\hline No. 293: Why do Governments Sell Privatised Companies Abroad? & $\begin{array}{l}\text { Bernardo Bortolotti, Marcella } \\
\text { Fantini and Carlo Scarpa }\end{array}$ & Mar. 2000 \\
\hline $\begin{array}{l}\text { No. 292: Going Public in Poland: Case-by-Case Privatizations, Mass } \\
\text { Privatization and Private Sector Initial Public Offerings }\end{array}$ & Wolfgang Aussenegg & Dec. 1999 \\
\hline $\begin{array}{l}\text { No. 291: Institutional Technology and the Chains of Trust: Capital } \\
\text { Markets and Privatization in Russia and the Czech Republic }\end{array}$ & Bruce Kogut and Andrew Spicer & Mar. 1999 \\
\hline No. 290: Banking Crises and Bank Rescues: The Effect of Reputation & Jenny Corbett and Ja & Jan. 2000 \\
\hline $\begin{array}{l}\text { No. 289: Do Active Labor Market Policies Help Unemployed Workers } \\
\text { to Find and Keep Regular Jobs? }\end{array}$ & Jan C. van Ours & Feb. 2000 \\
\hline No. 288: Consumption Patterns of the New Elite in Zimbabwe & ll Belk & Feb. 2000 \\
\hline $\begin{array}{l}\text { No. 287: Barter in Transition Economies: Competing Explanations } \\
\text { Confront Ukranian Data }\end{array}$ & $\begin{array}{l}\text { Dalia Marin, Daniel Kaufmann } \\
\text { and Bogdan Gorochowskij }\end{array}$ & Jan. 2000 \\
\hline $\begin{array}{l}\text { No. 286: The Quest for Pension Reform: Poland's Security through } \\
\text { Diversity }\end{array}$ & $\begin{array}{l}\text { Marek Góra and Michael } \\
\text { Rutkowski }\end{array}$ & Jan. 2000 \\
\hline No. 285: Disorganization and Financial Collapse & $\begin{array}{l}\text { Dalia Marin and Monika } \\
\text { Schnitzer }\end{array}$ & Oct. 1999 \\
\hline No. 284: Coordinating Changes in M-form and U-form Organizations & $\begin{array}{l}\text { Yingyi Qian, Gérard Roland and } \\
\text { Chenggang Xu }\end{array}$ & May 1999 \\
\hline $\begin{array}{l}\text { No. 283: Why Russian Workers Do Not Move: Attachment of Workers } \\
\text { Through In-Kind Payments }\end{array}$ & Guido Friebel and Sergei Guriev & Oct. 1999 \\
\hline No. 282: Lessons From Fiascos in Russian Corporate Governance & $\begin{array}{l}\text { Merritt B. Fox and Michael A. } \\
\text { Heller }\end{array}$ & Oct. 1999 \\
\hline $\begin{array}{l}\text { No. 281: Income Distribution and Price Controls: Targeting a Social } \\
\text { Safety Net During Economic Transition }\end{array}$ & $\begin{array}{l}\text { Michael Alexeev and James } \\
\text { Leitzel }\end{array}$ & Mar. 1999 \\
\hline $\begin{array}{l}\text { No. 280: Starting Positions, Reform Speed, and Economic Outcomes in } \\
\text { Transitioning Economies }\end{array}$ & William Hallagan and Zhang Jun & Jan. 2000 \\
\hline No. 279 : The Value of Prominent Directors & $\begin{array}{l}\text { Yoshiro Miwa \& J. Mark } \\
\text { Ramseyer }\end{array}$ & Oct. 1999 \\
\hline No. 278: The System Paradigm & János Kornai & Apr. 1998 \\
\hline $\begin{array}{l}\text { No. 277: The Developmental Consequences of Foreign Direct } \\
\text { Investment in the Transition from Socialism to Capitalism: The } \\
\text { Performance of Foreign Owned Firms in Hungary }\end{array}$ & Lawrence Peter King & Sept. 1999 \\
\hline $\begin{array}{l}\text { No. 276: Stability and Disorder: An Evolutionary Analysis of Russia's } \\
\text { Virtual Economy }\end{array}$ & $\begin{array}{l}\text { Clifford Gaddy and Barry W. } \\
\text { Ickes }\end{array}$ & Nov. 1999 \\
\hline $\begin{array}{l}\text { No. 275: Limiting Government Predation Through Anonymous } \\
\text { Banking: A Theory with Evidence from China. }\end{array}$ & $\begin{array}{l}\text { Chong-En Bai, David D. Li, } \\
\text { Yingyi Qian and Yijiang Wang }\end{array}$ & July 1999 \\
\hline
\end{tabular}




\begin{tabular}{|c|c|c|}
\hline No. 274: Transition with Labour Supply & Tito Boeri & Dec. 1999 \\
\hline $\begin{array}{l}\text { No. 273: Sectoral Restructuring and Labor Mobility: A Comparative } \\
\text { Look at the Czech Republic }\end{array}$ & Vit Sorm and Katherine Terrell & Nov. 1999 \\
\hline $\begin{array}{l}\text { No. 272: Published in: Journal of Comparative Economics "Returns to } \\
\text { Human Capital Under the Communist Wage Grid and During the } \\
\text { Transition to a Market Economy" Vol. 27, pp. 33-60 1999. }\end{array}$ & $\begin{array}{l}\text { Daniel Munich, Jan Svejnar and } \\
\text { Katherine Terrell }\end{array}$ & Oct. 1999 \\
\hline $\begin{array}{l}\text { No. 271: Barter in Russia: Liquidity Shortage Versus Lack of } \\
\text { Restructuring }\end{array}$ & $\begin{array}{l}\text { Sophie Brana and Mathilde } \\
\text { Maurel }\end{array}$ & June 1999 \\
\hline $\begin{array}{l}\text { No. 270: Tests for Efficient Financial Intermediation with Application to } \\
\text { China }\end{array}$ & Albert Park and Kaja Sehrt & Mar. 1999 \\
\hline $\begin{array}{l}\text { No. 269a: Russian Privatization and Corporate Governance: What Went } \\
\text { Wrong? }\end{array}$ & $\begin{array}{l}\text { Bernard Black, Reinier Kraakman } \\
\text { and Anna Tarassova }\end{array}$ & May 2000 \\
\hline $\begin{array}{l}\text { No. 269: Russian Privatization and Corporate Governance: What Went } \\
\text { Wrong? }\end{array}$ & $\begin{array}{l}\text { Bernard Black, Reinier Kraakman } \\
\text { and Anna Tarassova }\end{array}$ & Sept. 1999 \\
\hline No. 268: Are Russians Really Ready for Capitalism? & Susan Linz & Sept. 1999 \\
\hline No. 267: Do Stock Markets Promote Economic Growth? & $\begin{array}{l}\text { Randall K. Filer, Jan Hanousek } \\
\text { and Nauro Campos }\end{array}$ & Sept. 1999 \\
\hline $\begin{array}{l}\text { No. 266: Objectivity, Proximity and Adaptability in Corporate } \\
\text { Governance }\end{array}$ & $\begin{array}{l}\text { Arnoud W.A Boot and Jonathan } \\
\text { R. Macey }\end{array}$ & Sept. 1999 \\
\hline $\begin{array}{l}\text { No. 265: When the Future is not What it Used to Be: Lessons from the } \\
\text { Western European Experience to Forecasting Education and Training in } \\
\text { Transitional Economies }\end{array}$ & $\begin{array}{l}\text { Nauro F. Campos, Gerard } \\
\text { Hughes, Stepan Jurajda, and } \\
\text { Daniel Munich }\end{array}$ & Sept. 1999 \\
\hline $\begin{array}{l}\text { No. 264: The Institutional Foundation of Foreign-Invested Enterprises } \\
\text { (FIEs) in China }\end{array}$ & Yasheng Huang & Sept. 1999 \\
\hline $\begin{array}{l}\text { No. 263: The Changing Corporate Governance Paradigm: Implications } \\
\text { for Transition and Developing Countries }\end{array}$ & $\begin{array}{l}\text { Erik Ber } \\
\text { von Tha }\end{array}$ & June 1999 \\
\hline No. 262: Law Enforcement and Transition & $\begin{array}{l}\text { Gerard Roland and Thierry } \\
\text { Verdier }\end{array}$ & May 1999 \\
\hline $\begin{array}{l}\text { No. 261: Soft Budget Constraints, Pecuniary Externality, and the Dual } \\
\text { Track System }\end{array}$ & Jiahua Che & June 2000 \\
\hline $\begin{array}{l}\text { No. 260: Missing Market in Labor Quality: The Role of Quality Markets } \\
\text { in Transition }\end{array}$ & Gary H. Jefferson & July 1999 \\
\hline $\begin{array}{l}\text { No. 259: Do Corporate Global Environmental Standards in Emerging } \\
\text { Markets Create or Destroy Market Value }\end{array}$ & $\begin{array}{l}\text { Glen Dowell, Stuart Hart and } \\
\text { Bernard Yeung }\end{array}$ & June 1999 \\
\hline No. 258: Public Training and Outflows from Unemployment & Patrick A. Puhani & June 1999 \\
\hline $\begin{array}{l}\text { No. 257: Ownership Versus Environment: Why are Public Sector Firms } \\
\text { Inefficient? }\end{array}$ & $\begin{array}{l}\text { Ann P. Bartel and Ann E. } \\
\text { Harrison }\end{array}$ & June 1999 \\
\hline $\begin{array}{l}\text { No. 256: Taxation and Evasion in the Presence of Exortion by } \\
\text { Organized Crime }\end{array}$ & $\begin{array}{l}\text { Michael Alexeev, Eckhard Janeba } \\
\text { and Stefan Osborne }\end{array}$ & Nov. 1999 \\
\hline No. 255: Revisiting Hungary's Bankruptcy Episode & $\begin{array}{l}\text { John P. Bonin and Mark E. } \\
\text { Schaffer }\end{array}$ & Sept. 1999 \\
\hline No. 254: FDI in Emerging Markets: A Home-C & Marina v.N Whitman & June 1999 \\
\hline $\begin{array}{l}\text { No. 253: The Asian Financial Crisis: What Happened, and What is to be } \\
\text { Done }\end{array}$ & $\begin{array}{l}\text { Jeffrey D. Sachs and Wing Thye } \\
\text { Woo }\end{array}$ & Jan. 1999 \\
\hline No. 252: Organizational Law as Asset Partitioning & $\begin{array}{l}\text { Henry Hansmann and Reinier } \\
\text { Kraakman }\end{array}$ & Sept. 1999 \\
\hline $\begin{array}{l}\text { No. 251: Consumer Behavior Research in Emerging Consumer Markets: } \\
\text { the Case of the Optimum Stimulation Level in South Africa }\end{array}$ & $\begin{array}{l}\text { Jan-Benedict E. M. Steenkamp } \\
\text { and Steven M. Burgess }\end{array}$ & Sept. 1999 \\
\hline $\begin{array}{l}\text { No. 250: Property Rights Formation and the Organization of Exchange } \\
\text { and Production in Rural China }\end{array}$ & $\begin{array}{l}\text { Matthew A. Turner, Loren } \\
\text { Brandt, and Scott Rozelle }\end{array}$ & July 1998 \\
\hline $\begin{array}{l}\text { No. 249: Impacts of the Indonesian Economic Crisis: Price Changes and } \\
\text { the Poor }\end{array}$ & $\begin{array}{l}\text { James Levinsohn, Steven Berry, } \\
\text { and Jed Friedman }\end{array}$ & June 1999 \\
\hline $\begin{array}{l}\text { No. 248: Internal Barriers in the Transition of Enterprises from Central } \\
\text { Plan to Market }\end{array}$ & Charalambos Vlachoutsicos & July 1999 \\
\hline $\begin{array}{l}\text { No. 247: Spillovers from Multinationals in Developing Countries: the } \\
\text { Mechanisms at Work }\end{array}$ & Richard E. Caves & June 1999 \\
\hline
\end{tabular}

